Bu makaleye atıfta bulunmak için/To cite this article:

ÇIKMAK, S. UNGAN, M. C. (2021). Otomotiv Sektöründeki Tedarik Zinciri Riskleriyle İlgili Bir Araștırma.

Atatürk Üniversitesi Sosyal Bilimler Enstitüsü Dergisi, 25 (4), 1710-1737.

\title{
Otomotiv Sektöründeki Tedarik Zinciri Riskleriyle İlgili Bir Araștırma
}

\author{
Sinan $\operatorname{CCIKMAK}^{(*)}$ \\ Mustafa Cahit UNGAN ${ }^{(* *)}$
}

Öz: Tedarik zinciri riskleri tedarik zinciri ă̆ının farklı noktalarda ortaya çıkabilmektedir. Tedarik zinciri üyelerinin maliyetlerini arttıracak olan risklerin ve bu riskleri oluşturan risk faktörlerinin belirlenmesi riskleri önlemek veya olumsuz etkilerini azaltmak günümüz işletmelerinin ihtiyaç duydukları bir meseledir. Bu çalı̧̧mada, otomotiv sektörü tedarik zincirini tehdit eden risklerin belirlemesi ve risklerin birbirlerine olan etkilerinin analiz edilmesi amaçlanmıştır. Çalışmada nitel araştırma yöntemi kullanılmıştır. Araştırmanın evrenini Türkiye'deki otomotiv sanayisinde faaliyet gösteren ve ISO 500 listesinde yer alan üretim ișletmelerindeki tedarik zinciri yöneticileri olușturmaktadır. Kasti örnekleme yöntemiyle 15 farkl firmadan 20 tedarik zinciri yöneticisiyle yar yapılandırılmış derinlemesine görüşmeler gerçekleştirilmiştir. Elde edilen verilerin analiz edilmesinde betimsel yöntem kullanılmışıtı. Araştırmada bazı ana bulgulara ulaşılmıştır. Bunlardan birincisi, tedarik kaynaklı risklerin lojistik maliyetlerin artmasına ve teslim sürelerinin uzamasına neden olmasıdır. İkincisi, taşıma işlemlerindeki gecikmelerin taşımacılık risk faktörlerinden en önemlisi olduğudur. Üçüncüsü ise üretim risk faktörlerinin diğer risklerle karşılaştırıldı̆̆ında daha kolay kontrol edilebildiğidir. Türkiye'de otomotiv tedarik zinciri riskleri konusunda, yöneticilerden elde edilen verilerin analiz edildiği ilk araştırma olması nedeniyle bu çalışma literatüre önemli bir katkı sağlamaktadır.

Anahtar Kelimeler: Tedarik zinciri riskleri, risk faktörleri, otomotiv sektörü.

\section{A Study on Supply Chain Risks in the Automotive Industry}

Abstract: Supply chain risks may emerge at different points of a supply chain network. To prevent risks or reduce their harmful effects, contemporary organizations need to identify risks, which increase the costs of the supply chain members and the risk factors, which create these risks. This study aims to identify the risks that threaten the automotive supply chain and analyze the effects of the risks on each other. The qualitative research method was used. The population consists of supply chain managers of automotive manufacturing industry companies operating in Turkey and included in the ISO 500 list. For the data collection, the intentional sampling method was used, and semi-structured in-depth interviews were conducted with 20 supply chain managers from 15 different companies. A descriptive approach was used to analyze the data. There are some key findings of this study. First, supply-related risks cause increased logistics costs and longer delivery times. Second, the most crucial transportation risk factor is the delay in the transportation processes. Third, production risk factors can be controlled more efficiently compared to other risks. This study makes an essential contribution to the literature as it is the first to analyze supply chain risk data collected from Turkey's automotive sector managers.

\footnotetext{
*) Öğr. Gör. Dr., Düzce Üniversitesi Sosyal Bilimler MYO Yönetim ve Organizasyon Bölümü (eposta: sinancikmak@duzce.edu.tr) (D ORCID ID. https://orcid.org/0000-0002-4704-3409

${ }^{* *}$ Prof. Dr., Sakarya Üniversitesi İșletme Fakültesi İșletme Bölümü (e-posta: ungan@sakarya.edu.tr) (D) ORCID ID. https://orcid.org/0000-0003-2041-1344

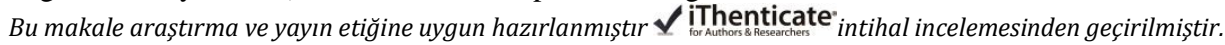


Keywords: Supply chain risks, risk factors, automotive industry.

Makale Geliş Tarihi: 06.06.2021

Makale Kabul Tarihi: 21.12.2021

DOI:10.53487/ataunisosbil.948617

\section{Giriş}

Modern işletmeler, hızla değişen karmaşık bir çevrede faaliyet gösterirlerken, sürekli olarak maliyet ve kalite baskıları altında doğru miktarda, istenilen zamanda ve yerde mal ve hizmet sunmak için karmaşık tedarik zinciri ağlarına giderek daha fazla bağımlı hale gelmişlerdir (Munir vd., 2020). Kısalan ürün yaşam süreleri, maliyet baskıları, artan rekabet ve küreselleşmeyle birlikte tedarik zincirleri genişlemiş ve sistemdeki düğüm noktalarının sayısı artmıştır (Tang \& Musa, 2011: 25). Ürün çeşitliliğinin ve yeni ürün sunum sıkılığının arttırılması, daha fazla ve çeşitli pazarlara açılma, tam zamanında üretim, dış kaynak kullanımı ve tedarikçi sayısının azaltılması gibi uygulamalar tedarik zincirlerinin risklere karşı kırılganlığını ve hassasiyetini arttırmıştır (Ceryno vd., 2015: 1145; Sodhi \& Tang, 2012: 6). Tedarik zincirindeki aksaklıklara neden olan riskler işletmenin operasyonlarında aksamalara, ürünlerin pazara sunumunda gecikmelere veya kritik hizmetlerin sunumuna engel olabilmektedir (Jüttner vd., 2003: 198). Bu nedenle tedarik zincirini tehdit eden risklerin belirlenmesi ve risklerin neden olduğu aksamaların değerlendirilmesi gerekmektedir. Ayrıca etkileri hala devam eden Covid-19 salgını tedarik zinciri risk yönetiminin önemini arttırmıştır (Üstündağ ve Ungan, 2021: 109).

Dünyada otomotiv sektörü ülke ekonomilerine önemli katkılar sağlayan, teknolojik gelişmeleri artıran, doğrudan veya dolaylı etkileşimde olduğu çok çeşitli sektörlerin gelişiminde lokomotif görevi gören bir sektördür (Pişkin, 2017: 12). Bu nedenle, otomotiv sektöründe ortaya çıkacak olan sorunlar geniş bir alana etki edecektir. Otomotiv tedarik zinciri oldukça karmaşık olup birbirleriyle bağlantılı birçok süreçten meydana gelmektedir. Bir aracın oluşturulmasında çok sayıda montaj parçasının kullanılması, bu parçaların tedarik edilmesinde çok sayıda tedarikçiyle çalışılması ve tüm zincir boyunca malzeme, bilgi ve finansal akışın koordine edilmesi otomotiv tedarik zincirini karmaşık hale getirmektedir (Zhu, 2018: 4). Tedarik zinciri yapısının karmaşık olması ve zincir üyeleri arasındaki yakın işbirlikleri nedeniyle otomotiv sektörü, tedarik zinciri risklerinin incelenmesi bakımından uygun bir sektördür (Thun \& Hoenig, 2011: 245). Son yıllarda otomotiv sektörü tedarik zinciri risklerinde artış yaşanması nedeniyle finansal ve operasyonel performanslarda düşüşler görülmektedir. Örneğin JLT sigorta tarafından 2018 yılında yayınlanan rapora göre sadece ABD'de otomotiv endüstrisinde tedarik zinciri kesintilerinde \%30 artış gözlemlenmiştir (Junaid vd., 2020). Bu nedenle otomotiv sektöründeki tedarik zinciri risklerinin değerlendirilmesi önemi her geçen gün artmaktadır. Diğer yandan, doğrudan otomotiv sektöründeki tedarik zinciri risklerini analiz eden çalışmaların sayısı yetersiz bulunmaktadır (Ceryno vd., 2015: 1146; Thun \& Hoenig, 2011: 243; Zhu, 2018: 4). İşte bu nedenlerden dolayı çalışmada, Türkiye otomotiv sektörünün tedarik zinciri risklerine odaklanılmıştır.

$\mathrm{Bu}$ çalışmanın temel amacı, literatürde yer alan tedarik zinciri riskleri ve risk faktörlerinin otomotiv sektöründeki tedarik zinciri yöneticileri tarafindan nasıl 
değerlendirildiğinin belirlenmesidir. Bu kapsamda aşağıdaki araştırma sorularına cevap aranmıştır:

1) Otomotiv sektörünü tehdit eden tedarik zinciri riskleri ve risk faktörleri nelerdir?

2) Otomotiv tedarik zinciri risklerini artıran unsurlar nelerdir?

3) Otomotiv tedarik zinciri risklerinin ve risk faktörlerinin etkileri nelerdir?

Makalenin geri kalanı şu şekilde yapılandırılmıştır: ikinci bölümde literatür incelemesi başlığı altında tedarik zinciri risklerinden bahsedilmiştir. Üçüncü bölümde, araştırma metodolojisi sunulmuştur. Dördüncü bölümde, otomotiv sektöründeki tedarik zinciri yöneticileriyle yapılan görüşmelerin analizi neticesinde elde dilen bulgulara ve yorumlara yer verilmiştir. Beşinci bölümde, tartışma kısmı oluşturulmuştur. Son bölümde ise, sonuç ve önerilere yer verilerek çalışma sonlandırılmıştır.

\section{Literatür İncelemesi}

\section{A. Tedarik Zinciri Riskleri}

Risk basitçe, tehlike ya da birtakım kayıplara maruz kalma durumu olarak ifade edilebilir (Schlegel \& Trent, 2014: 2). Tedarik zinciri bağlamında ise risk, operasyonel, taktiksel veya stratejik düzeyde başarısızlıklara veya düzensizliklere yol açan tedarik zincirinin herhangi bir bölümünü olumsuz etkileyen beklenmedik makro ve / veya mikro düzey olayların veya koşulların olasılığı ve etkisi olarak tanımlanmıştır (Ho vd., 2015: 5035). Tedarik zinciri riski, ilk tedarikçiden son müşteriye kadarki süreçte meydana gelen bilgi, malzeme ve ürün akışlarına ilişkin aksamaları kapsamaktadır (Jüttner vd., 2003: 202).

Tedarik zincirlerindeki aksamalar, kapasite kısıtları, makine arızaları, belirsiz üretim, kalite problemleri, operasyonel sorunlar, zayıf iletişim gibi değişen konularda kendisini çok farkı şekillerde gösterebilmektedir (Blackhurst vd., 2005). Ayrıca, dünyanın çeşitli bölgelerinde meydana gelen terör saldırıları, savaşlar, depremler, salgınlar, ekonomik krizler işletmelerin tedarik zincirleri akışını zor duruma sokmaktadır. 2000 yılında Phillips Elektronik'in mikroçip üretimini gerçekleştirdiği fabrikasında çıkan yangın nedeniyle müşterisi Ericsson üretimini bir ay boyunca durdurmak zorunda kalmış ve bu aksaklık Ericsson'u 400 milyon dolar zarara uğratmıştır (Chopra \& Sodhi, 2004: 53). Japonya'da 2011 yılında meydana gelen deprem ve tusunami felaketi ardından ortaya çıkan nükleer kriz, Toyota'nın üretimini 40,000 araca kadar düşürmesine sebep olmuş ve durum Toyota'nın her gün için 72 milyon dolar kaybetmesine yol açmıştır (Pettit vd., 2013: 46). Aralık 2019'da Çin'in Vuhan ortaya çıkan Covid-19 virüsü çok kısa sürede tüm dünyaya yayılarak küresel çapta halk sağlığını tehdit etmeye başlamış ve ülkeler çeşitli kısıtlamalar uygulamak zorunda kalmıştır. Salgın nedeniyle fabrikaların tamamen ya da kısmen kapatılması, havalimanlarındaki ve sınır geçişlerindeki sınırlamalar bu kısıtlamalardan bazılarıdır (Sarkis, 2020). Ülkelerin uyguladıkları karantinalar küresel tedarik zincirinde yıkıcı etkilere sebep olmuştur (Üstündağ ve Ungan, 2021: 117). Sonuç olarak dünya otomotiv üretimi, 2019'da 92,5 milyon olurken ve 2020 yılında salgının etkisiyle bu rakam 78 milyona inmiştir (KPMG, 2021: 3). 2021 yılında ise araçlarda kullanılan mikroçiplerin tedarik ve teslimat süreçlerindeki aksamalar sebebiyle tüm dünyada otomotiv firmalarının üretimlerine ara vermesine neden olarak, otomotiv sektöründe küresel bir kriz ortaya çıkmıştır. Bu krizin etkileri her geçen gün artarken 
otomotiv üreticilerinin çözüm yolları geliştirme çabaları devam etmektedir (Wu vd., 2021).

Firmalar çoğu kez, tedarikçilerinin söz verdikleri zamanda teslimatları yerine getirmeme sorunuyla karşılaşmaktadırlar. Örneğin 2006 yılında Sony firmasının ürünü olan Sony Play Station 3'ün tedarikçi problemleri nedeniyle pazara sunumunda gecikmeler yaşanmış ve bu durum Sony'nin hem gelir kaybına uğramasına hem de pazar payının azalmasına sebep olmuştur (Sodhi \& Tang, 2012: 4). Otomobil üreticisi Land Rover, bir tedarikçisinin iflas etmesi nedeniyle 1400 çalışanını işten çıkarmak zorunda kalmıştır (Sodhi \& Tang, 2012: 4). Tedarikçilerin kusurlu ürün göndermesinden kaynaklanan ve milyonlarca dolar zarara neden olan diğer bir örnek ise 2005 yılının başlarında meydana gelmiştir. Tamamlayıcı parça üreten Bosch firmasının, dizel yakıtlı enjeksiyon sistemleri için ürettiği yüksek basınçlı pompaları kusurlu çıkmıştır. $\mathrm{Bu}$ hatanın Bosch'un alt tedarikçisi olan bir firmadan kaynaklandığı tespit edilmiş olsa da zincirin tümünü etkileyen bu hata önemli maddi zararlara neden olmuştur (Thun \& Hoenig, 2011: 243). Mayıs 2017'de direksiyon dişlilerin tedarik sorunu nedeniyle BMW'deki üretim kesintiye uğramıştır. BMW'nin birinci kademe tedarikçisi olan Bosch'un bir tedarikçisindeki makine arızaları nedeniyle bazı direksiyon parçalarının üretimindeki gecikme direksiyon dişlilerinin teslimatını aksatmışıtır (Dolgui \& Ivanov, 2021: 103).

Farklı sebeplerden dolayı meydana gelen riskler işletmelerde çok çeşitli olumsuz sonuçlara neden olmaktadır. Ceryno vd. (2015: 1151) çalışmalarında meydana gelen risklerin sonuçlarını sıralamışlardır. Bunlar; satış kayıpları, maliyetlerde artı̧̧, finansal kayıplar, ürün kalitesinin azalması, sosyal kayıplar, müşterilerin hayatını riske sokan veya güvenliğine yönelik tehditlerin ortaya çıkması, olumsuz işletme imajı veya itibar kaybı ve ürün teslimlerinde gecikmeler şeklinde ortaya çıkan olumsuz sonuçlardır. $\mathrm{Bu}$ nedenle işletmelerin tedarik zincirindeki risklere karşı hazırlıklı olabilmeleri ve risklerin etkilerinden kendilerini koruyabilmeleri için öncelikle bu riskleri tanımlayabilmeleri, etkilerinin yanı sıra aralarındaki neden sonuç ilişkilerini de değerlendirmeleri gerekmektedir.

Literatürde tedarik zinciri risklerini tanımlamada farklı sınıflandırmalara yer verilmektedir. Tedarik zinciri risk yönetimi yazınında temel çalışmalardan birini hazırlamış olan Chopra \& Sodhi (2004), tedarik zinciri risklerini dokuz temel kategoride incelemiş̧lerdir. Bu risk türleri; bozulmalar, gecikmeler, bilgi sistemleri, tahmin, fikri mülkiyet, tedarik, alıcılar, envanter ve kapasite riskleridir. Wagner \& Bode (2008) riskleri; talep, tedarik, düzenleyici ve yasal riskler, altyapısal ve katastrofik riskler ana başlıkları ile ele almış ve her bir risk grubuna ait alt riskleri tanımlamışlardır. Blackhurst vd. (2008) tedarik zinciri risklerini, bozulmalar/afetler, lojistik kaynaklı riskler, tedarikçi bağımlılı̆̆ riski, kalite riskleri, bilgi sistemleri riskleri, tahmin riskleri, yasal düzenlemelerle ilgili riskler, fikri mülkiyet riskleri, satın alma/tedarik riskleri, alacaklarla ilgili riskler, envanter riskleri, yönetim riskleri, kapasite riskleri ve son olarak güvenlik riskleri olmak üzere 14 farklı kategoride değerlendirmişlerdir. Manuj \& Mentzer (2008) temelde kalitatif ve kantitatif riskler olarak sinıflandırdıkları tedarik zinciri risklerini küresel anlamda daha anlaşııı bir kategori geliştirerek 8 farklı riske ayırmışlardır. Wagner \& Bode (2008) tedarik zinciri risk kaynaklarını 5 farklı sınıfta değerlendirmiş̧lerdir: talep yönlü riskler, tedarik yönlü riskler, yasal ve bürokratik 
riskler, altyapı ve katastrofik riskler. Samvedi vd. (2013) riskleri çıkış noktalarına göre tedarik, talep, süreç ve çevresel olarak ele almışlardır. Tedarik riskleri; dış kaynak kullanımı, tedarikçi iflası, kalite ve maliyetlerdeki ani artış (zam), talep riskleri; ani dalgalanmalar, piyasa değişiklikleri, rekabet değişiklikleri ve tahmin hataları, süreç riskleri; makine arızaları, işçi grevi, kalite problemleri, teknolojik değişim ve son olarak çevresel riskleri ise terör, siyasi istikrarsızlık, doğal afetler, ekonomik sıkıntılar, sosyal ve kültürel sorunlar alt risklerinden oluşmaktadır. Venkatesh vd. (2015) riskleri ana başlıklar altında sınıflandırmaksızın küreselleşme, hammadde ve ürünün kalite standartları, kaynak yetersizliği, tedarikçi belirsizliği, koordinasyon yetersizliği, çalışan davranışları, altyapısal riskler, program gecikmeleri, talep belirsizliği, müşteri tatminsizliği, finansal risk, güvenlik ve emniyet riski olarak incelemișlerdir.

Tedarik zincir risk yönetimi literatüründe çok çeşitli risklerden ve risk sınıflandırmalarından bahsedilmektedir. Genel bir bakış açısı sunması için farklı araştırmacıların çalışmalarında yer verdikleri tedarik zinciri risk türleri ve sinıflandırmaları Tablo 1'de gösterilmektedir.

Tablo 1: Literatürde Yer Alan Tedarik Zinciri Risk Türleri

\section{Yazarlar Risk Türleri}

Harland vd. Stratejik, operasyon, tedarik, müşteri, şirket varlıklarının değer kaybetmesi, (2003) rekabet, itibar, finansal, mali, yasal düzenleme ve hukuki riskler

Jüttner vd. Çevresel, ağ kaynaklı ve organizasyonal riskler

(2003)

Cavinato

(2004)

Fiziksel, finansal, enformasyon, ilişkisel ve inovasyonel riskler

Chopra \& Bozulma, gecikme, bilgi sistemleri, tahmin, fikri mülkiyet, tedarik, alıcılar, Sodhi (2004) envanter ve kapasite riskleri

Christopher Firma içi riskler; süreç ve kontrol riskleri.

\& Peck Firma dişındaki fakat tedarik zinciri ağındaki riskler; talep ve tedarik riskleri

(2004) Tedarik zinciri dışındaki riskler; çevresel riskler

Operasyonel riskler; belirsiz müşteri talebi, belirsiz tedarik ve belirsiz maliyet.

Tang (2006) Bozulma riskleri; terör saldırıları, ekonomik krizler, devalüasyonlar, grevler, depremler, sel baskınları, kasırgalar

Wu vd. İçsel riskler; kontrol edilebilir, kısmen kontrol edilebilir ve kontrol edilmez riskler Dışsal riskler; kontrol edilebilir, kısmen kontrol edilebilir ve kontrol edilmez riskler

Blackhurst Bozulmalar/afetler, lojistik, tedarikçi bağımlılığı, kalite, bilgi sistemleri, tahmin, vd. (2008) yasal düzenlemeler, fikri mülkiyet satın alma/tedarik, alacaklar, envanter,

Manuj \&

Mentzer (2008)

Tang \&

Tomlin

(2008)

Tedarik, operasyonel, talep, güvenlik, makro, politik, rekabet ve kaynak riskleri

Tedarik, süreç, talep, fikri mülkiyet, davranışsal ve politik/sosyal riskler 
Wagner \& Bode (2008)

Talep yönlü, tedarik yönlü, yasal ve bürokratik, altyapı ve katastrofik riskler

Trkman \& Endojen(içsel) riskler; pazar ve teknoloji türbülansları.

McCormack Ekzojen(dışsal) riskler; ayrık olaylar (terör saldırıları, bulaşıcı hastalıklar, işçi (2009) grevleri ve sürekli olaylar (enflasyon oranı, tüketici fiyat endeksi değişiklikleri)

Kumar vd. İç operasyonel riskler; talep, üretim ve dağıtım riskleri, tedarik riskleri (2010) Diş operasyonel riskler; terörist saldırılar, doğal afetler, döviz kuru dalgalanmaları

Olson \&

Dash Wu Dişsal riskler; doğal olaylar, siyasal sistem, rakip ve pazar riskleri

(2010)

Ravindran

vd. (2010)

Lin \& Zhou

(2011) İçsel riskler; kapasite kullanımı, iç operasyon ve bilgi sistemleri riskleri

Riske maruz değer (Value at risk); grev, terör saldırıları ve doğal afet riskleri Hedefi 1skalamak (Miss the target); geç teslimat, kalite gereksinimlerinin karşılanmama riskleri

Tang \&

Musa (2011)

Tummala \& Schoenherr (2011)

Sodhi \&

Tang (2012)

Samvedi vd. (2013)

Punniyamoor thy vd. (2013) İçsel riskler; AR-GE, planlama, üretim, bilgi ve organizasyon yapısı riskleri Dışsal riskler; politika, tedarik ve teslimat riskleri

Malzeme akışı, finansal akış ve bilgi akışı riskleri

Talep, gecikme, bozulma, envanter, üretim (süreç) bozulmaları, kapasite, tedarik (satın alma), sistem, ülke ve taşımacılık riskleri

Tedarik, süreç, talep ve işletme düzeyi riskler

Tedarik, süreç, talep ve çevresel riskler

Makro riskler

Ho vd. (2015) Mikro riskler; talep, üretim, tedarik ve alt yapı riskleri (bilgi sistemleri, taşımacılık ve finansal riskler)

Planlama; strateji, durağanlık, bilgi sistemleri, kapasite ve talep riskleri

Tedarik; satınalma, finansal ve ilişki riskleri

Rangel vd. Üretim; operasyonel ve bozulma riskleri

(2015) Dağıtım; müşteri riski

İade; yasal risk

Diğer; çevresel ve kültürel riskler

Prakash vd.

Tedarik, talep, kontrol, süreç ve çevresel riskler

Shahbaz vd.

(2019)

Chu vd. (2020)

Tedarik, süreç, talep, lojistik, işbirliği, finansal, çevresel riskler

Politik, çevresel, finansal, tedarik ve talep, lojistik, sistem ve operasyonel riskler

Tedarik zinciri risklerinin incelendiği çalışmalarda, bir kısım araştırmacılar herhangi bir sınıflandırmaya gerek duymadan araştırma konularıyla ilgili riskleri değerlendirmişlerdir. Risklerin işletmeden işletmeye bağlamı değişmekle birlikte 
evrensel bir sınıflandırma yapmaktansa risklerin sistematik olarak tanımlanmasının daha uygun olacağı düşünülmektedir. Dolayısıyla bu çalışmada literatürdeki sınıflandırmalar göz önünde bulundurularak riskler; tedarik, üretim, talep, bilgi sistemleri, taşımacılık, finansal ve çevresel risk kategorilerinde ele alınmıştır.

\section{Araştırmanın Metodolojisi}

\section{A. Araştırmanın Tasarımı}

Çalışmada otomotiv sektörü tedarik zincirini tehdit eden risklerin belirlemesi ve risklerin birbirleriyle olan ilişkilerinin uygulayıcıların gözünden değerlendirilmesi amaçlanmaktadır. Gerçek yaşam bağlamında meydana gelen olayları anlamak ve keşfetmek için nitel yöntemlerden yararlanılmaktadır (Leedy \& Ormrod, 2014). Çalışmanın amacına ulaşabilmek için kişilerin görüşlerinin, anlayışlarının ve algılarının incelendiği nitel araştırma tasarımı kullanılmıştır (Percy vd., 2015: 78). Nitel araştırmalar, gözlem, görüşme ve doküman analizi gibi veri toplama yöntemlerinin kullanıldığ , algıların ve olayların doğal ortamda gerçekçi ve bütüncül bir biçimde ortaya konulmasını sağlayan nitel bir sürecin izlendiği çalışmalardır (Yıldırım ve Şimşek, 2013: 45).

Araştırmada belirli aşamalar takip edilmiştir. Çalışmanın temel amacının belirlenmesinden sonra tedarik zinciri riskleriyle ilgili kapsamlı literatür taraması yapılarak yazında yer alan tedarik zinciri riskleri ve risk faktörleri belirlenmiştir. Literatürdeki risklerin ve risk faktörlerinin sayısının çok fazla olması, konunun çok genişleyerek katılımcılardan doğru bilgiye erişimi zorlaştıracağı düşüncesiyle risklerin bir kısmı elenmiştir. Risklerin ve risk faktörlerinin belirlenirken üretim yönetimi ve tedarik zinciri yönetimi konusunda uzmanlaşmış 2 akademisyenden görüş alınmıştır. Söz konusu eleme işlemi sonucunda 6 risk türü ve bu risk türlerini oluşturan toplam 31 risk faktörü tedarik zinciri yöneticilerinin değerlendirmelerine sunulmuştur (Tablo 2). Ardından verilerin elde edilmesi amacıyla otomotiv sektöründeki tedarik zinciri yöneticileriyle yarı-yapılandırılmış derinlemesine mülakat tekniği kullanılarak görüşmeler gerçekleştirilmiştir. Nitel araştırmalarda en yaygın kullanılan veri toplama aracı olan yarı-yapılandırılmış mülakat tekniği, önceden hazırlanan sorulara göre başlayan, ancak görüşme esnasında araştırmacının bağımsız sorular sorabildiği bir yöntemdir (Lune \& Berg, 2017: 68). Yarı yapılandırılmış görüşmeler, araştırmacıların fenomen hakkında daha derin bir iç görü toplamasına veya katılımcıların tutumlarını, gerçeklerini, süreçlerini, deneyimlerini, tahminlerini veya davranışlarını keşfetmelerine olanak tanır (Cooper \& Schindler, 2014). Son olarak tamamlanan mülakatların ardından elde edilen veriler nitel veri analizi yöntemlerinden olan betimsel analiz yaklaşımı ile düzenlenmiş ve yorumlanmıştır.

Tablo 2. Yöneticilerin Değerlendirdikleri Tedarik Zinciri Riskleri Türleri ve Risk Faktörleri

\begin{tabular}{lll}
\hline Risk Türleri & Risk Faktörleri & Yazarlar \\
\hline \multirow{2}{*}{ Talep Riski } & Talep bilgisinin hatalı olması & Olson \& Wu (2010) \\
\cline { 2 - 3 } & Talep belirsizliği & Hahn \& Kuhn (2012) \\
\hline
\end{tabular}




\begin{tabular}{|c|c|c|}
\hline & Talep değişkenliği & Nakandala vd. (2017) \\
\hline \multirow{7}{*}{ Üretim Riski } & İş kazaları & Wagner \& Bode (2008) \\
\hline & İş gücü kaynaklı aksamalar & Tuncel \& Alpan (2010) \\
\hline & Makine arızaları & Samvedi vd. (2013) \\
\hline & Stok yetersizliği & Qazi \& Akhtar, (2020) \\
\hline & Stok fazlalı̆̆g & Nakandala vd. (2017) \\
\hline & Üretim kapasitesi & Tang \& Musa (2011) \\
\hline & $\begin{array}{l}\text { Hatalı üretimden kaynaklanan } \\
\text { aksamalar }\end{array}$ & Schlegel \& Trent (2015) \\
\hline \multirow{7}{*}{ Tedarik Riski } & $\begin{array}{l}\text { Tedarikçinin talep miktarındaki } \\
\text { değişimleri karş1layamaması }\end{array}$ & $\begin{array}{l}\text { Olson \& Wu (2010), Ho vd. } \\
\text { (2015) }\end{array}$ \\
\hline & $\begin{array}{l}\text { Tedarik edilen ürünlerin istenilen } \\
\text { kalitede olmaması }\end{array}$ & $\begin{array}{l}\text { Kull \& Talluri (2008), Hahn \& } \\
\text { Kuhn (2012) }\end{array}$ \\
\hline & Yanlış tedarikçi seçimi & Tummala \& Schoenherr (2011) \\
\hline & $\begin{array}{l}\text { Tedarikçinin malzemeleri zamanında } \\
\text { teslim edememesi }\end{array}$ & $\begin{array}{l}\text { Kull \& Talluri (2008), Schlegel \& } \\
\text { Trent (2015) }\end{array}$ \\
\hline & Tedarikçiye bağımlı olma & Tummala \& Schoenherr (2011), \\
\hline & $\begin{array}{l}\text { Tedarik edilen malzemelerde fiyat } \\
\text { artış1 }\end{array}$ & Samvedi vd. (2013) \\
\hline & $\begin{array}{l}\text { Tedarikçinin tasarım değişimlerini } \\
\text { karşılayamaması }\end{array}$ & Lin \& Zhou (2011) \\
\hline \multirow{4}{*}{$\begin{array}{l}\text { Taşımacılık } \\
\text { Riski }\end{array}$} & $\begin{array}{l}\text { Gümrük işlemelerinde yaşanan } \\
\text { sorunlar }\end{array}$ & Dittmann (2014), Ho vd. (2015) \\
\hline & $\begin{array}{l}\text { Taşıma işlemlerinin zamanında } \\
\text { yapılmaması }\end{array}$ & Tummala \& Schoenherr (2011) \\
\hline & Taşıma maliyetlerinde ani artış & Tummala \& Schoenherr (2011) \\
\hline & $\begin{array}{l}\text { Taşıma sırasında hasarların meydana } \\
\text { gelmesi }\end{array}$ & Venkatesh vd. (2015) \\
\hline \multirow{4}{*}{ Finansal Risk } & Döviz kuru dalgalanmaları & Kumar vd. (2010) \\
\hline & Faiz oranlarındaki değişim & Samvedi vd. (2013) \\
\hline & Düşük kar marjı & Ho vd. (2015) \\
\hline & Ürün maliyetlerindeki artış & Tummala \& Schoenherr (2011) \\
\hline \multirow{6}{*}{ Çevresel Risk } & Yangınlar & Vanany vd. (2009) \\
\hline & Doğal felaketler & Lawrence vd., (2020) \\
\hline & Savaş ve terör riski & Kumar vd. (2010) \\
\hline & Siyasi Belirsizlikler & Olson \& Wu (2010), \\
\hline & Ekonomik krizler & Samvedi vd. (2013) \\
\hline & Yasal düzenlemeler & Venkatesh vd. (2015) \\
\hline
\end{tabular}




\section{B. Araştırmanın Evren ve Örneklemi}

Otomotiv sektöründe genel olarak; binek otomobil, minibüs, midibüs, otobüs, kamyonet, van, kamyon, çekici ve traktör üretimleri gerçekleştirilmektedir (Otomotiv Sektörü Raporu, 2020: 9). Türkiye otomotiv ana sanayinde faaliyet gösteren ve traktör üreticileri dahil olmak üzere toplam 14 işletme bulunmaktadır (OSD, 2020). Ayrica otomotiv yan sanayinden faaliyet gösteren ilk 500 firma arasında yer alan otomotiv yan sanayisi konumunda 28 işletme bulunmaktadır (İSO 500, 2020). Araştırmanın evrenini Türkiye otomotiv sanayisinde faaliyet gösteren ve İSO (İstanbul Sanayi Odası) ilk 500 arasına girmiş üretim işletmelerindeki tedarik zinciri yöneticileri oluşturmaktadır. Nitel araştırmalarda genellikle görüşme ve gözlem yönteminin kullanılması, elde edilen bilginin yoğunluğu örneklem büyüklüğü üzerinde sınırlılıkları beraberinde getirmektedir. (Yıldırım ve Şimsek, 2013: 135). Ayrıca nitel araştırmalarda, nicel araştırmalarda olduğu gibi istatistiksel formüller kullanılarak örneklem büyüklüğü belirlenmemekle birlikte bu konuda farklı sayıda önerilerde bulunmaktadır (Baltacı, 2018: 260). Örneğin bazı yazarlar 3 ila 10 kişi ile çalışmanın yeterli olabileceğini söylerken, başka bir yazar ise bir olgu bilim araştırmasının en az 10 kişi ile yürütülmesini önermektedir (Baltacı, 2018: 262). Bu nedenle çalışmada, olasılığa dayalı olmayan örnekleme yöntemlerinden kasti (amaçlı) örnekleme kullanılmıştır. Kasti örnekleme yönteminde, örneği oluşturan katılımcılar araştırmacının araştırma sorularına cevap bulacağına inandığı kişilerden oluşmaktadır (Altunışık vd., 2012: 142). Araştırmanın örneklemini 15 farklı firmadan 20 tedarik zinciri yöneticisi oluşturmuştur. Bu kapsamda Türkiye otomotiv ana sanayinde faaliyet gösteren 11 işletmeden 16 katılımcı ile otomotiv yan sanayinde yer alan 4 işletmeden 4 katılımcı olmak üzere toplamda 20 tedarik zinciri yöneticisiyle yarı yapılandırılmış derinlemesine mülakatlar gerçekleştirilmiş. Tablo 2'de görüşme yapılan firmalarla ilgili sektör bilgisi, üretilen ürünler ve çalışan sayıları verilmiştir. Francis vd. (2010: 6), katılımcılarla yapılan mülakatlarda üst üste 3 görüşmeden yeni bilgiler sağlanamadığı takdirde veri doygunluğu noktasına ulaşıldığı belirtmişlerdir. Çalışma kapsamında, tedarik zinciri yöneticileriyle yapılan son 3 görüşmede tekrar eden benzer değerlendirmelerin yapıldığı görüldüğü için 20 . görüşmeden sonra veri toplama süreci tamamlanmıştır. Görüşme yapılan katılımcılar tedarik zinciri yönetimi alanında yüksek deneyime sahip yöneticilerdir. Tablo 3 'te görüleceği üzere katılımcıların otomotiv sektöründe sahip oldukları deneyim ve işletmelerinde görev aldıkları pozisyonlar konu ile ilgili verdikleri bilginin kalitesini ve güvenilirliğini sağlamaktadır (Meyer vd., 2019: 5).

Tablo 3: Görüşme Yapılan Tedarik Zinciri Yöneticilerinin Firma Bilgileri, Unvan ve Deneyimleri

\begin{tabular}{llcclc}
\hline Kod Unvan & Deneyim & Sektör & Üretilen Ürünler & $\begin{array}{c}\text { Çalışan } \\
\text { Sayısı }\end{array}$ \\
\hline K1 & Tedarik Zinciri Direktörü & 8 yıl & Yan sanayi & Sızdırmazlık Profilleri & 1250 \\
K2 & Lojistik Müdürü & 6 yıl & Yan sanayi & $\begin{array}{l}\text { Süspansiyon ve direksiyon } \\
\text { parçaları }\end{array}$ & 2300 \\
K3 & Lojistik Müdürü & 8 yıl & Yan sanayi Şasi ve Mekanizma & 1980 \\
K4 & Üretim Kontrol ve Satınalma & 11 yıl & Yan sanayi & Kapı çerçevesi, kapı kolu & 820 \\
K5 & Malzeme Yönetimi Şefi & 4 yıl & Ana sanayi & Otomobil & 770 \\
\hline
\end{tabular}




\begin{tabular}{|c|c|c|c|c|c|}
\hline K6 & Satınalma Müdürü & $10 \mathrm{y} 1 \mathrm{l}$ & Ana sanayi & Otomobil & 5200 \\
\hline K7 & $\begin{array}{l}\text { Tedarik Zinciri Geliştirme } \\
\text { Müdürü }\end{array}$ & $12 \mathrm{y} 11$ & Ana sanayi & Otomobil/Kamyonet & 6700 \\
\hline K8 & Satınalma Müdürü & $12 \mathrm{y} 1 \mathrm{l}$ & Ana sanayi & Minibüs/Kamyonet/Otomobil & 7500 \\
\hline K9 & Tedarik Zinciri Müdürü & $14 \mathrm{y} 1 \mathrm{l}$ & Ana sanayi & Minibüs/Kamyonet/Otomobil & 7500 \\
\hline K10 & Lojistik Birim Yöneticisi & $10 \mathrm{y} 1 \mathrm{l}$ & Ana sanayi & $\begin{array}{l}\text { Midibüs/Kamyon/Kamyonet/ } \\
\text { Otobüs }\end{array}$ & 2150 \\
\hline K11 & İthalat Müdür Yardımcısı & $13 \mathrm{y} 1 \mathrm{l}$ & Ana sanayi & Otomobil & 2800 \\
\hline K12 & Genel Müdür & $15 \mathrm{y} 1 \mathrm{l}$ & Ana sanayi & Otomobil & 5200 \\
\hline K13 & $\begin{array}{l}\text { Talep ve Üretim Planlama } \\
\text { Müdürü }\end{array}$ & $14 \mathrm{y} 1 \mathrm{l}$ & Ana sanayi & Otomobil/Kamyonet & 6700 \\
\hline K14 & $\begin{array}{l}\text { Malzeme ve Araç Lojistik } \\
\text { Müdürü }\end{array}$ & 7 y1l & Ana sanayi & Minibüs/Kamyonet/Otomobil & 7500 \\
\hline K15 & Üretim Direktörü & 14 y1l & Ana sanayi & $\begin{array}{l}\text { Midibüs/Kamyon/Kamyonet/ } \\
\text { Otobüs }\end{array}$ & 2150 \\
\hline K16 & Satınalma Müdürü & $18 \mathrm{y} 1 \mathrm{l}$ & Ana sanayi & Otobüs & 3500 \\
\hline K17 & Tedarikçi Yönetim Müdürü & $17 \mathrm{y} 1 \mathrm{l}$ & Ana sanayi & Otobüs & 3500 \\
\hline K18 & $\begin{array}{l}\text { Tedarikçi Yönetimi ve } \\
\text { Lojistik Müdürü }\end{array}$ & $12 \mathrm{y} 1 \mathrm{l}$ & Ana sanayi & Kamyon & 1800 \\
\hline K19 & Tedarik Zinciri Müdürü & 13 yil & Ana sanayi & Otomobil & 7180 \\
\hline K20 & Tedarik Zinciri Müdürü & $22 \mathrm{y} 11$ & Ana sanayi & Minibüs/Midibüs/Otobüs & 1050 \\
\hline
\end{tabular}

Türkiye otomotiv sanayisinde faaliyet gösteren 15 farklı firmadan 20 tedarik zinciri yöneticisinin her biriyle bir saati aşan mülakat yapılmıştır. Yöneticilerin talepleri gereği firma bilgileri ve yöneticilerin isimleri belirtilmemiş̧tir. Çalışma bulgularının sunumunda etik kurallar gereği görüşülen tedarik zinciri yöneticilerinin isimleri yerine kodlar kullanılmıştır. Görüşmeler sürecinde elde edilen verilerin daha sonra detaylı analiz edilebilmesi için izin veren yöneticilerle yapılan mülakatlar ses kaydına alınmıştır.

\section{Verilerin Analizi}

Yöneticilerle yapılan görüşmeler yazılı dokümanlara dönüştürüldükten sonra betimsel analiz gerçekleştirilmiştir. Çeşitli yöntemlerle elde edilen verilerin öncesinde belirlenen başlıklar altında tasniflenerek ve yorumlanmasını içeren betimsel analizde araştırmacı, görüştüğü katılımcıların görüşlerini etkili bir biçimde yansıtabilmek amacıyla doğrudan alıntılara sıklıkla yer verebilmektedir. $\mathrm{Bu}$ analiz yöntemiyle amaçlanan, elde edilmiş bulguların okuyucuya özetlenmiş ve yorumlanmış bir biçimde sunulmasıdır (Yıldırım ve Şimsek, 2013: 256). Çalışmada, risk türleri ve bu riskleri oluşturan alt risk faktörleri birer tema ve alt tema olarak belirlenerek katılımcıların ifadeleri uygun temalara aktarılarak incelenmiştir.

\section{Bulgular}

Tedarik zinciri yöneticileriyle yapılan görüşmelerde, otomotiv tedarik zincirinin tehdit eden risklerin neler olduğu konusunda bilgilere ulaşılmıştır. Katılımcılardan riskler konusunda görüşleri alınırken literatürden derlenerek hazırlanan Tablo 2'deki risk faktörleri göz önünde bulundurularak değerlendirilmelerde bulunmaları istenmiştir. Bundan sonraki kısımda katılımcıların ortak görüşleri göz önünde bulundurularak daha önce önerilen risk türleri başlıkları altında otomotiv tedarik zinciri risk faktörleri ve aralarındaki ilişkiler ortaya konulmuştur. 


\section{A. Talep Riskleri}

Talep riski, ürün talebindeki dalgalanmalardan doğan aksaklıklar ile ilgilidir. Ve bu durum arz ve talep arasında boşluk oluşturarak işletmeleri olumsuz bir şekilde etkilemektedir (Samvedi vd., 2013: 2436). Talep riskini oluşturan faktörlerden talep bilgisinin hatalı olması, gelişmiş bilgi sistemleri, anlık bilgi paylaşımları ve sürekli güncellenen talep tahmin bilgileri sayesinde düşük bir olasılık olduğu yöneticilerin ortak ifadelerinde yer almıştır. Örneğin, satınalma müdürü K16 talep bilgisinin hatalı olmasıyla ilgili şunları söylemiştir:

"Otobüs üretiminde hangi parçadan kaç adet ihtiyaç var? Ne zaman sipariş verilmesi gerekir? Yazılım bunu belli bir ölçüde otomatik olarak hesaplayabilir.

Sistemler arası bazı kopukluklar çalışanın veriyi eksik veya hatalı girmesi nedeniyle nadir de olsa talep bilgileri hatal gelebiliyor."

Ağır ticari araç ve otobüs üretimi yapan işletmelerde talep belirsizliği ve talep değişkenliği önemli bir risk unsuru olarak görülürken, binek otomobil sektöründe talep risklerinin önemi biraz daha azalmaktadır. Bu durumun en önemli sebeplerinden biri de ağırlıklı olarak Türkiye pazarına ürünleri sunan ağır ticari araç ve otobüs üreticilerinin döviz kuru ve faiz oranlarının artışı gibi ekonomik olumsuzluklardan etkileniyor olmalarıdır. Binek otomobil sektöründe ise büyük oranda ihracata yönelik üretim yapıldığından talep riski etkisinin daha düşük düzeyde hissedildiği ifade edilmiştir.

Yöneticiler, otomotiv ana sanayi firmalarının ve tedarikçilerinin üretim planlarını bir yıl öncesinden tahmini olarak belirleyerek ve gerekli hazırlıkların tüm zincir boyunca yapıldığını belirtmişlerdir. Bütün siparişler ve tedarik süreçleri yıllık plana göre çalışmaktadır. Önceden belirlenmiş aralıklarla güncellenen talep tahmini bilgileri belirli bir tarihten sonra kesin siparişe dönüşmektedir. Çeşitli faktörlerin etkisiyle öngörü talebi veya kesin talep bilgisi ile gerçekleşen talep arasında farklılıklar ortaya çıkabilmektedir. Özellikle Türkiye pazarına yönelik üretim yapan işletmelerin talepleri ekonomik gelişmelerden, yasal düzenlemelerden, rekabet ve pazar koşullarından önemli ölçüde etkilenmektedir. Otomotiv sektöründe talep risk faktörleri konusunda ticari ve binek otomobil sektörü arasında önemli farklılıkların bulunduğu elde edilen sonuçlardan biridir.

Tedarik zinciri yöneticileriyle yapılan görüşmeler neticesinde Şekil 1'de gösterilen talep riskini artıran faktörler ve talep riskinin neden olduğu olumsuz durumlar tespit edilmiştir. Döviz kurundaki ve faiz oranlarındaki artışlar, tedarikçilerin talep değişimlerini karşılayamaması, hatalı tahminlerin yapılması, rekabetin yüksek oluşu, vergi oranlarındaki değişimlerin satışlara olan etkileri ve çeşitli nedenlerle meydana gelen hammadde yetersizlikleri talep risklerinin artmasina neden olmaktadır. Talep riskleri, siparişlerin müşterilerin istedikleri zamanda teslim edilememesi ve hammadde ve ürün stoklarının artmasına neden olabilmektedir. 


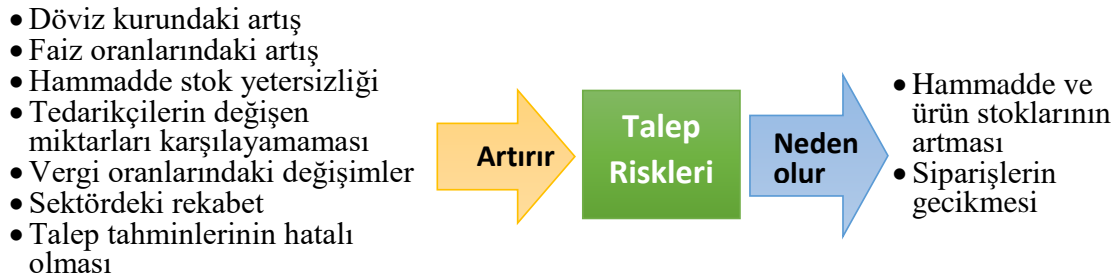

Şekil 1: Talep Riskini Artıran Unsurlar ve Talep Risklerinin Etkileri

\section{B. Tedarik Riskleri}

Tedarik riskleri, tedarikçilerden ya da arz pazarından kaynaklanan sorunların meydana gelme olasılıklarıyla ilgilidir (Manuj \& Mentzer, 2008: 138). Tedarik riskleri içerisinde yer alan tedarik edilen malzemelerde fiyat artışı riski görüşülen yöneticilerin çoğu tarafından işletmeyi tehdit edebilecek bir risk faktörü olarak değerlendirilmemiştir. Hatta tedarikçilerle yapılan anlaşmalar gereği aynı parçayı sağlayan tedarikçinin zamanla uzmanlaşacağı ve maliyetlerini azaltması gerektiği düşüncesiyle tedarikçilerden fiyat indirimlerinin istendiği tedarik zinciri yöneticilerinin ortak ifadelerinden biri olmuştur. Örneğin K1'in bu konudaki değerlendirmesi şöyledir;

"Tedarik edilen malzemelerde genel olarak fiyat artışı riski yaşanmamaktadır.

Tedarik edilen parçanın özelliklerinin değişiklik göstermesi durumunda veya sonradan tespit edilen bir kusur nedeniyle birtakım müdahaleler yapıldı̆̆ında maliyet artışı oluşuyorsa fiyat değişikliği meydana gelebilir. Ancak fiyat artışı, sadece özel durumlarda ve müş̧teri mutabakatıyla uygulanır."

Yöneticiler, tedarikçilerin talep değişimlerini karşılayamama riskine karşı her ne kadar tedarikçilerinin belirli bir düzeyde kapasite esnekliğine sahip olmaları konusunda çalışmalar yapıyor olsalar da söz konusu risk faktörünün çeşitli nedenlerden dolayı ortaya çıkabileceği belirtmişlerdir. Söz konusu risk faktörüyle ilgili olarak tedarikçi yönetim müdürü K17'inin ifadeleri şunlardır;

"Tedarikçinin değişen miktarları karşılayamaması durumunda ilk olarak tedarikçinin esnek kapasite uygulamalarına yer vermesi istenir. Fazla mesailer, hafta sonu çalışmaları, yeni kalıp yatırımı gibi yöntemler uygulanır. Bunlarda fayda vermez ise farklı tedarikçi veya farklı ürün arayışına gidilebilir."

Tedarik zinciri yöneticileri, üretilen araçların parçalarında 5 veya 6 yıl süreyle önemli değişiklikler olmadığını ifade etmişlerdir. Tedarikçilerden uzun süre tasarım değişikliklerinin istenmemesi nedeniyle tedarikçinin tasarım değişikliklerini karşılayamaması otomotiv tedarik zincirini tehdit eden bir risk faktörü olarak görülmemiştir. Bu konuda binek otomobil üreticisi bir firmanın ithalat müdür yardımcısı K11 şu ifadelere yer vermiştir;

"Otomobil üretiminde birkaç yıl boyunca üretilecek parçanın özellikleri değişiklik göstermez. Ancak bir takım mühendislik değişimleri uygulanmaktadır. Buradaki müdahaleler kalıp değişimi veya malzeme değişikliği gibi büyük çaplı değildirler. Bazı parçaların araca takılıp takılmayacağ veya kullanılan malzemenin kalitesinin arttırılması gibi iyileştirmeler yapılabilir." 
Tedarik zinciri yöneticilerinin ortak ifadelerine göre, otomotiv sektöründe tedarikçi seçimi, tedarikçilerin geliştirilmesi, tedarikçilerle uzun vadeli ilişkilerin kurulması çok önemli görülmektedir. Bu nedenle yanlış tedarikçi seçimi riski oldukça düşük olasılıklı bir risk faktörü olarak değerlendirilmiştir. Benzer şekilde tedarikçiye bağımlılık otomotiv sektörü için düşük düzeyli bir risk faktörü olarak değerlendirilmiştir. Özellikle otomotiv ana sanayinin, tedarikçilerinin birçoğu üzerinde uzun vadeli sözleşmelerle sağlanan hakimiyeti bulunmaktadır. Yöneticiler, tedarikçi ve müşteri ilişkisinin belirli bir finansal büyüklüğe sahip olması ve sürekli bir ilişkinin sağlanmasının tedarikçi bağımlılığ 1 riskinin azaltılmasında önemli olduğunu vurgulamışlardır. Bu konuda K3’ün şunları belirtmiştir;

"Tedarikçi bağımlılığl yok denecek kadar azdır. Ancak bazı özel parçaların tedarikçi sayısı az olduğu için belli bir düzeyde tedarikçi bă̆ımlılı̆̆ından bahsedilebilir. Bu durumda ise, tedarikçi ile uzun vadeli özel sözleşmeler yaparak malzeme tedariki güvence altına alınır."

Kendilerine soru yöneltilmemesine rağmen bazı tedarik zinciri yöneticileri tedarikçilerin finansal olarak kötü duruma düşmesinin kendileri için ciddi bir risk faktörü olduğunu belirtmişlerdir. Çünkü tedarikçide ortaya çıkacak finansal bir kriz tedarikçi faaliyetlerinin aksamasına neden olmakta ve müşteriye yapılan parça sevkiyatını kesintiye uğratmaktadır. Bu konuda ağır ticari araç üreticisi bir firmanın tedarikçi yönetim müdürü K17 şunları söylemiştir;

"Tedarikçilerin finansal durumu aylık olarak yakından takip edilir. Finansal

olarak riskte olan tedarikçiler tespit edilerek, yeni tedarikçi geliştirme planı veya

mevcut tedarikçinin finansal durumunu iyileştirme planı yapılır."

Yeni tedarikçiyle çalışma sürecinin uzun sürmesi nedeniyle işletmeler tedarikçideki olumsuz mali gidişatın erken tespit edilmesinin önemli olduğunu belirtmişlerdir.

Yukarıda sözü edilen risk faktörlerinin yanı sıra yöneticiler, tedarikçilerde çeşitli sebeplerden dolayı beklenmedik olumsuzlukların yaşanabileceğini belirtmişlerdir. Ve bu olumsuzlukların malzeme temininde aksamalara sebebiyet vereceğini vurgulamışlardır. Tedarikçide meydana gelen büyük makine arızları, hatalı parça üretimi, tedarikçinin hammadde temin edememesi, üretim ekipmanlarında özellikle kalıplarda ortaya çıkan sorunlar, yangınlar, doğal felaketler, mali krizler ve lojistik operasyonlarda meydana gelen aksamalar tedarikçinin malzemeleri zamanında ve istenilen miktarda ve kalitede teslim edememesine dolayısıyla da tedarik riskinin ortaya çıkmasına neden olabilmektedir. (Şekil 2)

- Tedarikçide büyük makine arizalar1

- Hatalı parça üretimi

- Kalıp sorunları

- Yanginlar

- Doğal felaketler

- Tedarikçideki mali krizler

- Tedarikçinin hammadde temin edememesi

- Lojistik aksamalar

- Beklenmedik lojistik maliyetler

- Kalite sorunları

- Teslimat gecikmeleri

- Üretim programının değişmesi

Şekil 2: Tedarik Riskini Artıran Unsurlar ve Tedarik Risklerinin Etkileri 


\section{C. Üretim Riskleri}

Literatürde süreç ve operasyonel riskler olarak ta ifade edilen üretim riskleri organizasyonun içsel faaliyetlerinde konumlanmışlardır. Bu durum işletmenin bu riskleri kontrol altına almasını kolaylaştırmaktadır (Schlegel \& Trent, 2014: 134). Özellikle otomotiv sektöründe yalın üretim ve sürekli iyileştirme gibi uygulamalar süreçleri hatasızlaştırma çabasındadır. Ancak, tüm bu iyileştirmeler tedarik zincirlerinin hata toleransının da azalmasına neden olmuştur (Deloitte, 2012: 3).

Aracı oluşturan binlerce parça bulunmaktadır. Bu parçaların, doğru miktarda, doğru zamanda, istenilen yerde hazır bulundurulması gerekir. Bu nedenle başarılı stok yönetimi yöneticiler tarafindan çok önemli görülmektedir. Stok yetersizliği nedeniyle istenen miktarda üretim gerçekleştirilemez ise talebin karşılanamaması riski ortaya çıkacaktır. Ancak, çeşitli sorunlara karşı stok seviyelerini arttırmak beraberinde stok fazlalığı riskini getirmektedir. Fazla stok bulundurmak işletmelerin maliyetlerinin artması, gerçek problemlerin perdelenmesi ve eldeki parçaların demode olması nedeniyle kullanılamaz duruma gelmesi gibi çeşitli sorunlara yol açmaktadır.

Yöneticiler, tedarikçilerde veya odak işletmede meydana gelebilecek makine arızalarının tedarik zincirinde aksamalara neden olabileceğini ifade etmişlerdir. Örneğin, tedarikçide meydana gelen makine arızası veya ekipman yetersizliği gibi durumlar malzeme tedarikini olumsuz etkileyebilir. Yöneticiler makine arılarından kaynaklanabilecek aksamaların çeşitli reaktif ve proaktif önlemlerle giderilebileceğini ifade etmişlerdir. Esnek kapasiteye sahip olunması, farklı makinelerle aynı işlemin gerçekleştirilmesi, üretim programının değiştirilmesi şeklinde uygulamalarla makine arızlarından kaynaklanacak gecikmelerin telafi edilebileceğini belirtmişlerdir.

Yöneticilere, iş kazalarının işletme faaliyetlerini hangi düzeyde etkilediği sorulmuştur. Tedarik zinciri yöneticileri, otomotiv sektöründe faaliyet gösteren firmaların iş güvenliğiyle ilgili önlemlerin alınması, gerekli denetim ve uygulamalar konusunda gelişmiş iş sağlığı ve güvenliği sistemine sahip olduklarını ifade etmişlerdir. Alınan tüm önlemlere rağmen yaşanan iş kazlarında ise üretim faaliyetlerini kesintiye uğratacak aksamaların yaşanmadığı belirtilmiştir. Otomotiv ana sanayindeki firmalar tedarikçilerinin de iş güvenliğinin sağlanması konusunda belirli bir yeterliliğe sahip olmasını istemektedirler. Bu konuda tedarikçi yönetim müdürü K17 şu ifadelere yer vermiştir:

"İş kazası kaynaklı duruşlar karşılaşılan bir durum değildir. Ancak önemsenmesi gereken önemli bir risk faktörü̈dür. Tedarikçilerin değerlendirilmesinde dahi iş güvenliği konularına yer verilerek iş güvenliği konusunda gerekli önlemleri aldikları kontrol edilmektedir."

İş gücü kaynaklı aksama riski konusundaki değerlendirmelerde iş gücü devamsızlı̆̆ (Tuncel \& Alpan, 2010) grevler (Wu vd., 2006), iş gücü kaynaklı hatalar, nitelikli iş gücünün kaybedilmesi veya yetersizliği (Ho vd., 2015) konularından bahsedilmiştir. Yöneticiler genel olarak iş gücü kaynaklı aksamaların üstesinden gelinebilecek sorunlar olarak gördüklerini ifade etseler de başarılı bir şekilde yönetilmesi gereken bir risk faktörü olduğunu da vurgulamışlardır. Bu konuda otomotiv yan sanayi işletmesinde üretim kontrol ve satın alma müdürü olarak görev yapan K4 şunları söylemiştir: 
"İşgücü kaynakl aksamalara karşl yine yedekleme mantığı devrededir. Ihtiyaç duyulan personelin \%1 fazlası bulundurulmaya çalışllır. Ayrıca işe gelmeyen çalıșanın yerine hatlarda ustabașı vb. görevlerde çalıșanlar gerektiğinde gelmeyen çalışanın yerine bakabilmektedir. Aynı hatta 5 kişi birden gelmez ise diğer hatlardan çoklu yeteneğe sahip çalı̧̧anlardan takviye yapılır."

Hatalı üretim, otomotiv ana sanayi ve yan sanayide karşılaşılan bir durumdur. Yöneticilerin hatalı üretimle ilgili en büyük endișesi hatanın müșteriye yansımasıdır. Özellikle otomotiv yan sanayi firma yöneticileri müşteriye gönderilen hatalı parçaların ana sanayinin faaliyetlerinin aksatmasından dolayı ceza almalarına ve hatta ana sanayi ile uzun vadeli ilişkilerin bozulmasına sebep olacağını belirtmişlerdir. Bu risk faktörüyle ilgili otomotiv yan sanayi ișletmesinde lojistik müdürü olan K3'ün değerlendirmeleri şöyledir:

"Hatalı parçalar üretimin önemli bir gerçeğidir. Burada önemli olan unsurlar, hatalı parçanın kaç adet olduğu ve doğurduğu kalitesizlik maliyetidir. Ayrica hatalı parçalar ana sanayiye gittiğinde tedarikçi notunu düsürebilmekte ve uzun vadeli iliskileri zora sokabilmektedir. Böyle bir durumda hatanın nereden kaynaklandı̆ğ tespit edilerek tekrar edilememesi için önlemler alınır."

\section{Taşımacılık Riskleri}

Taşımacılık riskleri, lojistik süreç boyunca firmanın veya ortaklarının lojistik sistemlerinden veya doğal afetlerden kaynaklanan gecikmelere veya kesintilere neden olan bir faktör olarak görülmektedir (Shahbaz vd., 2019). Taşımacılıktaki aksaklıklar, tüm tedarik zincirini etkileyerek operasyonların durmasına, satış kayıplarına, geç teslimatlara ve itibar kaybı gibi sorunlara yol açabilir (Garvey vd., 2015).

Dışsal bir risk faktörü olan gümrük işlemlerinde yaşanan sorunların mevzuattaki değişimlerden, sınır kapıları geçişlerindeki aksamalardan, evrak işlemlerindeki eksikliklerden/hatalardan ve gümrük tarifelerindeki değişikliler nedeniyle süreçlerdeki gecikmelerden kaynaklandığı uzmanlarca belirtilmiştir. Bu konudaki bazı yöneticilerin ifadeleri şunlardır:

"Belirli gümrüklerde sikintılar daha fazladır. Örneğin Güney Amerika ve Brezilya'dan gelen parçalarda sorunlar yașanabilmektedir. Bu bölgelerdeki sorunların kaynağl grevler, siyasi karışılklklar ve süreçlerin yavaş işlemesi şeklinde siralanabilir." (K9)

"Gümrüklerle ilgili başlica risk faktörü gümrük tarifelerinde değișikliklerin yaşanmasıdır. Bazı durumlarda gümrük ișlemleri nedeniyle malzemeler gecikebilmektedir." (K15)

Taşımacılık faaliyetlerinde çeşitli sebeplerden dolayı gecikmeler yaşanabilmektedir. Yöneticiler malzemenin tedarikinde mesafe arttıkça, özellikle deniz aşırı ülkelerden tedarik edilen parçalarda birtakım aksaklıkların çıkma olasılığının arttığını dile getirmişlerdir. Örneğin liman grevleri, olumsuz hava koşulları ve siyası karışıklıklar nedeniyle nakliye faaliyetlerinde gecikmelerin yaşandığı belirtilmiştir. Bu nedenle bazı otomotiv ana sanayi işletmeleri tedarikçilerinin yakın mesafelerde olmasını stratejik anlamda çok önemli bulduklarını ve tedarikçi seçiminde önem verilen unsurlardan biri olduğunu ifade etmişledir. 
Taşıma maliyetlerinde ani artışın bir risk unsuru olmadığg tüm yöneticilerin ortak görüşü olmuştur. Lojistik firmalarıyla yapılan yıllık anlaşmalar gereği beklenmedik ani değişimler yaşanmamaktadır. Taşıma maliyetlerinde artışlar döviz kurundaki dalgalanmalara da bağlıdır. Ancak akaryakıttaki fiyat artışının derhal maliyetlere yansıtılmadığı, belirli bir süreçte gerçekleştiği belirtilmiştir. Ayrıca yöneticiler, satışların ve ödemelerin döviz cinsinden gerçekleştirildiği için işletmelerde böyle bir riskin de ortaya çıkmayacağını ifade etmişlerdir. Bu risk faktörüyle ilgili bazı yöneticilerin değerlendirmeleri şu şekildedir:

"Taşıma maliyetlerin de ani artış yaşanmaz. Lojistik firmalarıla bir araya gelinerek bir yıllık sözleşme yapılır. Alanlarında uzman olan uluslararası lojistik hizmet sağlayıcıları gelecek firsat ve tehditlerin neler olacă̆ını, çalışılacak yılın risklerini ön görebilen profesyonel firmalardır. Tüm değişken ve sabit maliyetleri göz önünde bulunduran lojistik firmalar yillk sabit fiyatla otomotiv ana sanayisinin karşısına çıkmaktadır” (K11)

"Taşıma maliyetleri arttı̆̆ında eskalasyonlarla, fiyatlarda birtakım güncellemeler yapılır. Bu güncellemelerde karşılıklı anlaşmalarla belirlenmiş bir formül kullanilır.” (K10)

"Kara nakliyesinde temel maliyet kalemi akaryakıttır. Döviz kurundaki artışa bağlı olarak taşıma maliyetlerinde de artış söz konusudur. Ancak akaryakıttaki fiyat artışı derhal maliyetlere yansıtılmaz. Fiyat artışı belirli bir süreçte gerçekleşir." (K13)

Taşıma sırasında malzeme hasarlarının sık bir şekilde olmasa da meydana geldiği uzmanlarca belirtilmiştir. Malzemelerin konulduğu kasaların yorulması ve deformasyonu sonucunda parçalarda hasarlar meydana gelebilmektedir veya elleçleme esnasında kasaların devrilmesi ve parçaların zarar görmesi şeklide durumlar yaşanabilmektedir. Gelen parçalarda hasar durumu ortaya çıktığında sigortaya başvurulmakta veya kusur hangi tarafta ise maliyetin karşılanması istenmektedir. Burada önemli olan hasarlı malzeme nedeniyle üretim faaliyetlerinin aksayabilme ihtimalinin en aza indirilebilmesidir. Bu konuyla ilgili sırasıyla K17 ve K11'in ifadeleri şunlardır:

"Taşıma sırasında hasarlar meydana gelmektedir. Ancak sik tekrarlanan bir durum değildir. Taşıma sırasında malzemenin hasarlanması veya kullanılamaz hale gelmesi durumunda üretim sürecinin aksamaması için işletmeler emniyet stoğu bulundurmaktadır."

"Taşıma sırasında hasarların/kazaların meydana gelmesi durumunda sigorta zararı karşılamaktadır. Üretim aksamasına neden olabilecek durumlarda ise gemi ile getirilen malzemeler, tedarik sürecini hızlandırmak adına havayolu taşımacılı̆̆ kullanılarak getirilirler."

- Sinır geçișlerinde gecikmeler

- Yasal düzenlemeler

- Deniz aşırı ülkelerden tedarik

- Liman grevleri

- Olumsuz hava kosulları

- Siyasi karışıklıklar
- Ulaşıım rotalarının değiştirilmesi

- Ekspres nakliye

faaliyetlerinin

\section{Taşımacılık} Riskleri gerçekleştirilmesi

- Maliyet artışları

- Emniyet stoklarının artır1mas1 
Şekil 3: Tedarik Riskini Artıran Unsurlar ve Tedarik Risklerinin Etkileri

\section{E. Finansal Riskler}

Para akışıyla ilgili riskler finansal risklerdir. Tedarik zincirindeki finansal sorunlar sadece odak işletme ile sınırlı olmayıp tedarikçileri ve müşterileri de kapsamaktadır (Dellana \& West, 2016: 132). Yöneticilerin bir kısmı finansal risk faktörlerinin hepsi için değerlendirme yapmaktan kaçınmışlardır. Ancak görüşlerini bildiren katılımcıların da ortak değerlendirmeleri olmuştur.

Döviz kuru dalgalanmaları risk faktörü özellikle Türkiye'de meydana gelen döviz kurundaki artışlar çerçevesinde yöneticiler tarafindan değerlendirilmiştir. Döviz kurlarındaki artışların ithal edilen parçaların maliyetlerini artırması nedeniyle iç pazarda (Türkiye pazarında) otomobil fiyatlarının tırmanışa geçmesine ve bu nedenle Türkiye pazarındaki taleplerin önemli ölçüde azalmasına neden olduğu ifade edilmiştir.

“Otomotiv sektörünün özellikle binek otomobil üreticilerinin büyük oranda

ihracat yapması sayesinde Türkiye'deki döviz kuru artışlarından daha az etkilenmesini sağlamaktadır. Ancak döviz kurundaki artışın, farklı otomotiv ana sanayilerinde özellikle ihracatı az olan firmalardaki olumsuz etkileri tüm zincir boyunca ciddi şekilde hissedilir." (K19)

Faiz oranlarındaki ve döviz kurundaki artışın satın alma ve üretim maliyetlerinin artmasına ve özellikle Türkiye pazarında talebin azalmasına sebep olduğu belirtilmiştir. Ancak büyük oranda ihracata yönelik üretim yapan firmalar finansal risklerin olumsuz etkilerini ihracat paylarını arttırmaya çalışarak biraz daha hafifletmektedirler. Yapılan bir değerlendirme şöyledir:

"Faiz oranlarındaki ve döviz kurlarındaki artış riskine karşı diğer bir koruma yöntemi yurt dışı ihracat payını arttırmaktır. Hali hazırda firmamızın ihracat oranı \%80'in üzerindedir. Türkiye'de yaşanan döviz kuru kriziyle birlikte oran

birkaç puan daha arttırllarak \%86'ya çıkarılmıştır. Bu uygulama krizin etkisini önemli ölçüde azaltmıştır" (K9)

Otomotiv sektöründe rekabetin her alanda yüksek olmasının kar marjlarının düşmesine sebebiyet verdiği ifade edilmiştir. Pazarın belirli bir fiyat beklentisi içinde olması nedeniyle maliyetlerdeki artışın satış fiyatlarına yansıtılamaması kar marjının azaltmaktadır.

\section{F. Çevresel Riskler}

Çevresel riskler, zincir içindeki tek bir kademeyi ya da organizasyonu etkileyebileceği gibi tedarik zincirinin tümünü etki edecek olaylardan meydana gelebilir (Samvedi vd., 2013). Çevresel riskler çeşitli makalelerde makro riskler (Ho vd., 2015) veya dişsal riskler (Kumar vd., 2010; Trkman \& McCormack, 2009) olarak isimlendirilmektedir

Doğal felaketler tedarik zincirlerini farklı şekillerde etkileyerek daha önce denenmemiş çözüm yollarının geliştirilmesine sebep olabilmektedir. Yöneticiler söz konusu risk faktörleriyle ilgili gerçek örnekler vermişlerdir. Yöneticilerin doğal felaketler konusundaki ifadelerinden bazıları şunlardır:

"Doğal afet yaşandı. Örneğin dolu yă̆ış̧ meydana geldi ve stoktaki yaklaşık 15

bin araba zarar gördü. Yurtdışından ekipler getirilerek dolu hasarları vakum 
sistemi ile düzeltildi. Ve bu otomobiller $\% 5$ ila \%15 arasında indirimli fiyatlarla satıldl." (K11)

"Doğal afet riski lojistik operasyonları önemli ölçüde etkilemektedir. Bulgaristan'daki nehrin taşması karayolu ulaşımını zora sokmakta ve süreleri uzatmaktadır.” (K17)

"Doğal afet riskleri için reaktif uygulamalar daha yaygındır. Örneğin, Japonya'da ki deprem ve tsunami sonrasında meydana gelen nükleer santral sızıntısı nedeniyle fukuşima bölgesinden gelen parçalar için radyasyon testleri yapıldı. Ayr bir ambar kiralanarak, gelen parçalar iki günlük radyasyon kontrolünden geçtikten sonra üretime alınmıştır." (K18)

Bazı yöneticiler, siyasi belirsizliklerin ülke ekonomilerine olumsuz etkisinin tedarik zinciri faaliyetlerini etkileyebileceği veya küresel çapta siyasi krizlerin olumsuz etkilerinin olabileceği belirtmişlerdir. Özellikle son yıllarda ticaret savaşları olarak adlandırılan dünya ticaret hacminde büyük paya sahip devletlerin uyguladıkları ticari yaptırımların küresel tedarik zincirine olumsuz etkileri olabileceği ifade edilmiștir. Ancak çevresel risklerin içerisinde yer alan siyasi belirsizlikler ve savaş ve terör faktörlerinin birçok yönetici tarafından işletme faaliyetlerini aksatabilecek düşük olasılıklı riskler olarak değerlendirildiği görülmüştür.

İşletmelerde yangın risk faktörü iş sağlığı ve güvenliği kapsamında yönetilmektedir. Otomotiv ana sanayisindeki yöneticiler iş güvenliği ile ilgili çalışmaların titizlikle uygulandığını vurgulamışlardır. Ayrıca, tedarikçilerinin de iş sağlığı ve güvenliği konusunda belirli bir yeterliliğe sahip olması, birlikte çalışabilme şartları içerisinde yer almaktadır. Dolayısıyla yangın riskine karşı iş güvenliği kapsamında önlemlerin alındığı ifade edilmiştir. Buna rağmen yangın riski yöneticiler tarafindan çevresel riskler içinde önemli bir risk faktörü olarak değerlendirilmiştir. Çünkü geçmişte meydana gelen yangın vakaları bu riskin önemini artırmaktadır. Yangın riski ile ilgili yöneticilerin ifadelerinden bazıları şöyledir:

"Boyahane, otomotiv fabrikasında yatırım maliyeti yüksek en kritik bölümlerden biridir. Aynı zamanda yangın riski yüksek olan bir bölümdür. Burada çıkacak yangın fabrikanın bütün faaliyetlerini durdurabilir. Nitekim böyle bir yangın meydana geldi ve işletme yetkilileri günlerce sorunu çözmek için geceli gündüzlü çalışmak zorunda kaldılar." (K11)

"Örneğin, makas üreten bir tedarikçinin dökümhanesinde yangın meydana geldi. Bu olay meydana gelince bir takım oluşturuldu. Bu takım yeni bir tedarikçi bularak, en kısa zamanda sevkiyatın başlamasını sağlamıştır.” (K18)

"2011 yllında otomotiv ana sanayisine poliüretan parça üretimi yapan tedarikçide yangın meydana geldi. Ortaya çıkan ciddi olumsuzluk karşısında firmamı bazı parçaları alternatif tedarikçilere yaptırmıştır." (K9)

“Türkiye'deki tedarikçi firmanın deposunda çıkan yangın nedeniyle ana firmada aksama yaşanmaması için aynı tedarikçinin Çin ve Hindistan'daki fabrikalarından uçakla ihtiyaç duyulan parçalar getirilmiştir. " (K11) 
Tedarik zinciri yöneticilerine göre doğal felaketlerin ve yangınların neden olduğu sorunlar Şekil 4'de gösterilmektedir. Bunlar; malzeme temininde ve teslimatlar da gecikmeler, doğal felaketler nedeniyle ulaşım rotasının ve/veya taşıma modunun değiştirilmesi nedeniyle taşıma maliyetlerinin artması, yangınların sebep olduğu üretim aksamaları, stoktaki bitmiş ürün ve malzemelerin zarar görmesi şeklindedir.

Şekil 4: Doğal Felaketlerin ve Yangınların Olumsuz Etkileri
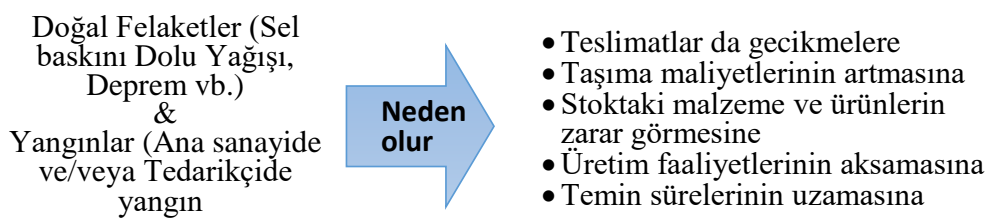

Yasal düzenlemelerin neden olabileceği sorunlar konusunda yöneticiler örnekler vererek değerlendirmelerde bulunmuşlardır. Yasal düzenlemeler kapsamında, gümrük işlemlerindeki değişimler, vergi düzenlemeleri, emisyon sınır değerlerindeki değişimler, farklı pazarlardaki yasal düzenlemelerden bahsedilmiştir. Ayrıca, yasal düzenlemelere uyum sağlamanın sadece Türkiye ile sınırlı olmadığı, aynı zamanda faaliyet gösterilen farklı ülkelerin mevzuat düzenlemelerinin de yakından takip etmenin gerekli olduğu vurgulanmıştır. Bu risk faktörüyle ilgili olarak yönetici değerlendirmeleri şunlardır:

"Yasalardaki değişimler özellikle maliyetler açısından risk oluşturabilmektedir. Artan maliyetler nedeniyle tedarikçi değişimlerine gidilebilir. Ayrica küresel çaptaki yasal düzenlemeler de otomotiv üreticisini zora sokabilmektedir." (K9)

"Yasal düzenlemelere en iyi örneklerden biride ÖTV indirimleridir. ÖTV teşvikinin uzatılıp uzatılmayacă̆l işletmenin önünde bir belirsizlik olarak durmaktadır. Avrupa'nın ileriye dönük emisyon düzenlemeleri otomotiv işletmenlerinin elektrikli araç üretimini hızlandırmalarına ve çeşitli yerlerdeki üretim faaliyetlerini sonlandırmasına veya değiştirmelerine neden olmuştur." (K5)

“Ülkemizde olmasa da Avrupa'daki yasal değişimler nedeniyle birtakım zorluklar yaşanabilmektedir. Örneğin çıkacak bir yasal düzenleme ile elde bulundurulan stokların işe yaramaması ya da büyük bir yenilemeden geçmesi zorunluluğu ortaya çıkabilir." (K20)

\section{Tartışma}

Talep riski, ürün talebindeki dalgalanmalardan kaynaklanmaktadır (Samvedi vd., 2013). Tedarik zinciri yöneticilerinin ifadelerine göre otomotiv sektöründe talep risklerini ortaya çıkaran ve arttıran unsurlar; döviz kurlarındaki artış, faiz oranlarındaki artış, vergi oranlarındaki değişim, sektördeki rekabet, malzeme tedarikinde yaşanan aksamalar ve hatalı öngörüler olarak sıralanmıştır. Talep riskini arttıran söz konusu bu faktörlerden sektördeki rekabet ve hatalı öngörülere neden olan yanlış talep tahminleri, talep risk faktörleridir. Döviz kurlarındaki artış ve faiz oranlarındaki artış finansal risk faktörleri kategorisindedir (Ho vd., 2015). Burada bazı finansal risk faktörlerinin talep riskini arttırdığı görülmektedir. Vergi oranlarında ki değişim yasal düzenlemelerden kaynaklanmaktadır. Yasal düzenlemeler ise çevresel bir risk faktörüdür. Malzeme 
tedarikinde yaşanan aksamalar (kalite, zaman ve miktar değişimleri) ise tedarik risk faktörü içinde ele alınmaktadır (Kull \& Talluri, 2008). Dolayısıyla araştırmada bulgularına göre otomotiv sektöründe talep riskini arttıran faktörlerden yalnızca ikisi literatürdeki talep risk faktörleri kategorisindedir.

Farklı çalışmalarda yer alan tedarik risk faktörlerinden bazılarının otomotiv tedarik zinciri için tehdit oluşturmadığı görülmüştür. Örneğin, tedarik edilen parçalarda fiyat artışını meydana gelmesi riski (Manuj \& Mentzer, 2008; Samvedi vd., 2013) tedarikçilerle yapılan bağlayıcı anlaşmalarla ortadan kaldırılmaktadır. Otomotiv sektörü teknolojik gelişmelerin odağında bir sektör olsa da ürün özelliklerindeki değişimler hızlı değildir. Dolayısıyla tedarikçilerin ürettiği parçaların özellikleri uzun süre değişmemektedir. Bunu sonucu olarak Lin \& Zhou (2011)'unun işaret ettiği tedarikçilerin tasarım değişimlerini karşılayamama riski otomotiv sektörünü tehdit eden tedarik risk faktörü olarak görülmemiştir. Otomotiv sektöründe tedarikçilerle ilişkiler çok güçlü tutulmak istenmektedir. Tedarikçilerin seçimi, takibi, gelişimi, uzun vadeli iş ilișkilerin devamlılığı oldukça önemlidir. Bu nedenle yanlıs tedarikçi seçimi (Tummala \& Schoenherr, 2011) düşük olasılıklı bir risk faktörü olarak değerlendirilmiştir. Özellikle otomotiv ana sanayisinde faaliyet gösteren işletmelerin tedarikçileri üzerinde hâkimiyet kurmalarının tedarikçi bağımlılı̆̆ riski olasılı̆̆ını azalttığı yöneticilerin ortak ifadesi olmuştur. Ancak günümüzde devam eden çip krizi tedarikçi bağımlılığının halen çok ciddi bir risk faktörü olduğunu göstermektedir.

Üretim risk faktörleri firma içi risklerle ilgilidir. Otomotiv işletmelerindeki yöneticiler, içsel faaliyetlerde ortaya çıkabilecek olan bu risklerin yönetiminin firma dışı risklere nazaran kolay olacağını vurgulamışlardır. Literatürle de paralel olarak stok bir risk faktörü olarak değerlendirilmiştir. Aynı zamanda stok arttırmak çeşitli risklerin olumsuz etkilerini azaltan bir araç olarak görülmektedir (Chopra \& Sodhi, 2004). Bu nedenle başarılı ve dengeli stok yönetimi son derece önemlidir. Gelişmiş üretim sistemlerine sahip olan ve yalın üretim, altı sigma ve tam zamanında üretim gibi uygulamalarla iç süreçlerini sürekli iyileştiren otomotiv işletmelerinin makine arızaları ve hatalı üretim risk faktörlerini kontrol altına aldıkları söylenebilir. Ancak, Sodhi \& Tang (2012) söz konusu uygulamalara rağmen üretim ve tasarım hataları nedeniyle araç geri çağırmalarının yaşanmaya devam ettiğini belirtmiştir.

Taşımacılık riskini oluşturan risk faktörleri kapsamında, sınır geçişlerindeki gecikmelerden, gümrük mevzuatı ve uygulamalarından kaynaklanan sorunlardan ve liman grevlerinden bahsedilmiştir. Benzer şekilde, Tennessee Üniversitesi tarafından hazırlanan raporda gümrük düzenlemelerindeki değisskenliğgin neden olduğu gecikmelere ve para cezalarına değinilmiştir (Dittmann, 2014: 21). Liman grevleri de uluslararası ticarette gecikmelere sebep olan taşımacılık risk faktörlerindendir (Ho vd., 2015; Tummala \& Schoenherr, 2011). Doğal afetler kategorisinde yer alan olumsuz hava koşulları tüm taşımacılık modlarında aksamalara neden olurken, küresel çapta tüm tedarik zincirlerinde ciddi sorunlara yol açmaktadır (Lawrence vd., 2020). Genel olarak taşımacılık faaliyetlerinde ortaya çıkan sorunlar tedarik zincirindeki bir düğümden diğerine teslimatın gecikmesi ve bunun sonucu olarak üretim faaliyetlerinin durması ve satış kayıplarının yaşanmasına sebep olabilir (Paul vd., 2020). Otomotiv sektöründeki yöneticiler işletmelerin taşımacılık risklerine karşı emniyet stokları bulundurduklarından bahsetmişlerdir. Ancak stok arttırma beraberinde maliyet arttırıcı sorunlara neden olan 
ayrı bir risk faktörüdür. Bu nedenle işletmelerin fazla stok bulundurma ile stoksuz kalma arasındaki hassas dengeyi yakalamaları gerekmektedir.

Finansal risk faktörleriyle ilgili bulgular incelendiğinde, Türkiye'de meydana gelen döviz kuru artışı riskinin vurgulandığı görülmüştür. Döviz kurlarındaki artış, ürün maliyetlerinin artışına, düşük kar marjına ve talebin azalmasına neden olmaktadır. Dolayısıyla finansal risk faktörlerinin zincirleme bir etkiye sahip olduğu görülmektedir. Ağırlıklı olarak Türkiye pazarına ürünlerini sunan kamyon ve otobüs üreticilerinin döviz kuru ve faiz oranlarının artışı nedeniyle araç satışları azalmaktadır. Ancak küresel pazarlarda faaliyet gösteren işletmelerin (otomobil ve hafif ticari araç üreticileri) ihracat paylarının yüksek olması sayesinde Türkiye pazarında ki döviz kuru artışıla meydana gelen ürün talebindeki azalmanın olumsuz etkisini daha az hissetmektedir.

Literatürde de sıklıkla bahsedilen doğal felaketlerin (Gurtu \& Johny, 2021; Lawrence vd., 2020; Mzougui vd., 2020) olumsuz etkileri, yöneticiler tarafından işletmelerinde yaşanmış örneklerle açıklanmıştır. Doğal felaketler taşımacılık faaliyetlerinde aksamalara sebebiyet vermekle ön plana çıkmaktadır.

Küresel bir tedarik zinciri yapısına sahip olan otomotiv sektörü, birden fazla ülkenin dâhil olduğu toplumsal / siyasi risklere maruz kalmaktadır (Sodhi \& Tang, 2012: 29). Otomotiv tedarik zinciri yöneticileri ise siyasi belirsizlik, savaş ve terör risklerini düşük olasılıklı riskler olarak değerlendirmişlerdir. Ancak Dittmann (2014) hazırladı̆̆ raporda işletme yöneticilerinin politik/toplumsal karışıklıkları önem sıralamasında listenin sonuna yerleştirmiş olsalar da firmaların bu riski göz ardı etmemeleri gerektiği vurgulamıştır.

\section{A. Çalıșmanın Önemi, Sınırlılıkları ve Gelecek Araştırmalar}

Yapılan bu çalışma sonrası elde edilen bulguların tedarik zinciri risk yönetimi yazınına katkı sağlayacağı düşünülmektedir. Literatürde, Türkiye'de otomotiv tedarik zinciri riskleri konusunda, tedarik zinciri yöneticileriyle mülakatlar yapılarak elde edilen verilerin analiz edildiği başka bir çalışmayla karşılaşılmamıştır. Görüşmeler esnasında tedarik zinciri yöneticilerinin gerçek tecrübelerine dayanan açıklamalarda bulunmaları tedarik zinciri riskleriyle ilgilenen uygulayıcıların ve akademisyenlerin bilgi birikimlerine katkı sağlayacaktır. Ayrıca bu çalışma tedarik zinciri riskleri konusunda yeni çalışmaların yapılması konusunda yol gösterici olacaktır.

Araştırmanın sınırlılıkları bulunmaktadır. Bunlardan ilki, mülakatların 2019 yılının aralık ayında tamamlanmış olması nedeniyle tedarik zinciri yöneticilerinden Covid19'un etkileri konusunda bilgiler alınamamasıdır. İkinci olarak, çalışmada yalnızca otomotiv tedarik zincirindeki ana sanayi işlemelerine ve birinci kademe tedarikçilere odaklanarak sınırlı bir alana yayılmıştır. Tedarik zincirinin kapsamı, ikinci ve üçüncü kademe tedarikçileri, distribütörleri, bayileri ve hatta müşterileri de içine alacak şekilde genişletilebilir.

Bundan sonra yapılacak çalışmalarda tedarik zinciri risklerine karşı hassasiyeti yüksek olan, risk faktörlerinin ve aralarındaki ilişkilerin tanımlanmasının önemli olduğu farklı sektörlerde araştırmaların yapılması faydalı olacaktır. Ayrıca kısıtlı risk faktörleri üzerine odaklanarak bunların zincir boyunca tedarik zinciri ortaklarında yaptığı etkilerin derinlemesine incelendiği gerçek vakalar üzerinde çalışmalar yapılabilir. Son olarak, 
tedarik zinciri risk yönetimi kapsamında Covid-19'un otomotiv tedarik zincirine etkileri konusunda kapsamlı bir çalışma yapılması faydalı olacaktır.

\section{Sonuç ve Öneriler}

Çok sayıda parçanın bir araya getirilerek oldukça kompleks bir ürünün üretildiği otomotiv sektörünün tedarik zinciri yapısı son derece geniş ve karmaşıktır. Otomotiv sektöründeki yüksek rekabet, ürün geliştirme sürelerinin kısalması, maliyet baskıları vb. tedarik zinciri yapısının kırılganlığını arttırmaktadır. Tedarik zinciri riskleri tüm sektörlerde olduğu gibi otomotiv sektörü tedarik zinciri yönetimini de zorlaştırmaktadır.

Yapılan bu çalışmayla, literatürde yer alan tedarik zinciri riskleri ve risk faktörlerinin otomotiv sektöründeki tedarik zinciri yöneticileri tarafından değerlendirilmesi amaçlanmıştır. Tedarik zinciri yöneticileriyle yapılan görüşmeler sonrasında, otomotiv sektörü tedarik zinciri risk faktörlerinin, riskleri artıran unsurların ve risklerin olumsuz etkilerini neler olduğu konusunda uygulayıcıların gözünden önemli bilgilere erişilmiş̧ir.

Otomotiv sektöründe talep risklerini ortaya çıkaran ve arttıran unsurlar; döviz kurlarındaki artış, faiz oranlarındaki artış, vergi oranlarındaki değişim, sektördeki rekabet, malzeme tedarikinde yaşanan aksamalar ve hatalı öngörüler şeklinde sırlanmıştır. Ekonomilerdeki olumsuz gelişmeler, yasal düzenlemelerdeki değişiklikler ve rekabet düzeyi talebi önemli ölçüde etkilemektedir. Talep riskleri, siparişlerin müşterilerin istedikleri zamanda teslim edilememesi ve hammadde ve ürün stoklarının artmasına neden olabilmektedir. Sonuç olarak işletmelerin rekabet avantajını kaybetmesine ve pazar payının azalmasına neden olabilecek talep risk faktörlerine karşı etkili stratejiler geliştirmeleri faydalı olacaktır.

Tedarik riskleri tedarikçi kaynaklı aksamalardan oluşmaktadır. Tedarikçilerde meydana gelen makine arızları, hatalı üretim, tedarikçinin hammadde temin edememesi, üretim kalıplarında ortaya çıkan sorunlar, yangınlar, doğal felaketler, tedarikçideki mali krizler ve nakliye operasyonlarında meydana gelen aksamalar ana sanayinin ihtiyaç duyduğu parçaları istenilen zamanda, miktarda ve kalitede tedarikçilerinden temin edememesine sebep olabilmektedir. Ayrıca müşteri talebindeki değişimlere bağlı olarak tedarikçilerin ihtiyaç duyulan malzemeleri karşılayamama sorunu da tedarik riski olarak değerlendirilmektedir. Tedarik kaynaklı riskler; lojistik maliyetlerin artması, üretilen ürünlerde kalite sorunlarının ortaya çıkması, üretim programının değişmesi ve teslim sürelerinin uzaması şeklinde olumsuz sonuçlar ortaya çıkarmaktadır. İşletmelerin tedarikçi kaynaklı aksamaların kök nedenlerini tespit etmeleri gerekli müdahaleleri yapabilmeleri ve önleme politikaları geliştirmeleri için oldukça önemlidir.

İşletmelerin içsel faaliyetleriyle ilgili olan üretim riskleri, çok çeşitli olmakla birlikte işletmelerin diğer tedarik zinciri riskleriyle karşılaş̧ırıldığında kontrol altına almakta daha az zorlandığı risklerdendir. Makine arızalarından kaynaklanan aksamalar işletme için önemli kesintilere sebebiyet verecek risk faktörü olarak görülmemektedir. Çünkü çok çeşitli reaktif ve proaktif uygulamalar ile arızaların neden olduğu kesintiler telafi edilebilmektedir. Stok yetersizliği ve fazlalığı sürekli olarak takip edilmesi gereken üretim risk faktörlerindendir. Makine arızaları, üretim hataları, iş gücü kaynaklı aksamalar vb. birçok üretim risk faktörüne karşı tutulan emniyet stokları, fazla stok riskine neden olabilmektedir. Bu nedenle optimum miktarda stok bulundurma çabaları çok önemlidir. 
Taşımacılık risk faktörlerinin en önemlisi taşıma işlemlerindeki gecikmelerdir. Malzemenin tedarikinde mesafe arttıkça, özellikle deniz aşırı ülkelerden tedarik edilen parçalarda birtakım aksaklıkların çıkma olasılı̆̆ı artmaktadır. Grevler, olumsuz hava koşulları, siyasi karışıklıklar veya süreçlerin yavaş işlemesi nedeniyle bazı ülkelerin sınır geçişlerinde gecikmelerin yaşandığı ifade edilmiştir. Diğer yandan taşımacılık faaliyetlerindeki aksamalara karşı, emniyet stoklarının arttırılması, ulaşım rotalarının değiştirilmesi ve ekspres nakliye faaliyetlerinin gerçekleştirilmesi maliyetlerin artmasına sebep olmaktadır. İşte bu noktada yöneticilerin risklerin olumsuz etkilerini azaltma maliyetlerini çok iyi analiz etmeleri gerekecektir.

Döviz kurlarının artışı, faiz oranlarındaki yükseliş ve vergi oranlarındaki değişim Türkiye pazarındaki ürün talebini önemli ölçüde azaltmıştır. Büyük oranda ihracata yönelik üretim yapan firmalar bölgesel finansal risklerin olumsuz etkilerini ihracat paylarını arttırarak hafifletmektedirler. Genel olarak dünya genelinde faaliyet gösteren birçok otomotiv fïması için küresel ekonomik krizler bölgesel krizlere nazaran daha büyük sorunlara neden olmaktadır. Ancak büyük oranda Türkiye pazarına ürün sunan ticari araç üreticileri yüksek faizlerden ve özellikle döviz kuru artışlarından çok ciddi etkilenmektedir.

Düşük olasılıklı risk faktörleri olarak görülen yangın ve doğal felaketlerle ilgili geçmişte yaşanmış vakalar bu risk faktörlerinin önemini ortaya koymaktadır. İşletmelerin kendi bünyelerinde ve tedarikçilerde meydana gelebilecek yangın ve doğal afet risklerine karşı acil eylem planlarının oluşturmaları ve birlikte çalıştıkları firmaların iş sağlığı ve güvenliği konusunda yeterli önlemleri almış olmalarının şart koşulması bu risk faktörlerinin önemsendiğinin göstergeleri arasındadır.

Tedarik zinciri riskleri ve risk faktörleri arasında karmaşık ilişkiler ağı mevcuttur. Literatürde belirli bir risk kategorisinde değerlendirilen bir risk faktörü tedarik zinciri ağında birçok noktada olumsuz etkiler oluşturabilir. Söz konusu bu etkiler zincirleme bir reaksiyon göstererek farklı tedarik zinciri risklerini tetikleyebilir. Tedarik zinciri yöneticilerinin ve araştırmacıların sektörel farklılıklarla birlikte risklerin karşılıklı ve zincirleme etkilerini göz önünde bulundurmaları faydalı olacaktır.

\section{Kaynaklar}

Altunışık, R., Çoşkun, R., ve Bayraktaroğlu, S. (2012). Sosyal Bilimlerde Araştırma Yöntemleri (7. Baskı). Sakarya Yayıncılık.

Baltacı, A. (2018). Nitel araştırmalarda örnekleme yöntemleri ve örnek hacmi sorunsalı üzerine kavramsal bir inceleme. Bitlis Eren Üniversitesi Sosyal Bilimler Dergisi, $7(1), 231-274$

Blackhurst, J., Craighead, C. W., Elkins, D., \& Handfield, R. B. (2005). An empirically derived agenda of critical research issues for managing supply-chain disruptions. International Journal of Production Research, 43(19), 4067-4081.

Blackhurst, Jennifer V., Scheibe, K. P., \& Johnson, D. J. (2008). Supplier risk assessment and monitoring for the automotive industry. International Journal of Physical Distribution \& Logistics Management, 38(2), 143-165.

Cavinato, J. L. (2004). Supply chain logistics risks: From the back room to the board 
room. International Journal of Physical Distribution \& Logistics Management, 34(5), 383-387

Ceryno, P. S., Scavarda, L. F., \& Klingebiel, K. (2015). Supply chain risk: Empirical research in the automotive industry. Journal of Risk Research, 18(9), 1145-1164.

Chopra, S., \& Sodhi, M. M. S. (2004). Managing risk to avoid: Supply-chain breakdown. MIT Sloan Management Review, 26(1),5 2-61

Christopher, M., \& Peck, H. (2004). Building the Resilient Supply Chain. The International Journal of Logistics Management, 15(2), 1-14.

Chu, C. Y., Park, K., \& Kremer, G. E. (2020). A global supply chain risk management framework: An application of text-mining to identify region-specific supply chain risks. Advanced Engineering Informatics, 45, 101053.

Cooper, D., \& Schindler, P. (2014). Business research methods (12. Bask1). McGrawHill.

Dellana, S., \& West, D. (2016). Survival analysis of supply chain financial risk. The Journal of Risk Finance, 17(2), 130-151

Deloitte. (2012). Supply Chain Resilience: A Risk Intelligent approach to managing global supply chains. Erișim adresi: https://www2.deloitte.com/global/en/pages/governance-risk-andcompliance/articles/risk-intelligent-approach-managing-supply-chains.html (Erişim tarihi: 17/08/2019)

Dolgui, A., \& Ivanov, D. (2021) Ripple effect and supply chaindisruption management: new trends and research directions, International Journal of ProductionResearch, 59(1), 102-109.

Francis, J. J., Johnston, M., Robertson, C., Glidewell, L., Entwistle, V., Eccles, M. P., \& Grimshaw, J. M. (2010). What is an adequate sample size? Operationalising data saturation for theory-based interview studies. Psychology and Health, 25(10), 1229 1245.

Garvey, M. D., Carnovale, S., \& Yeniyurt, S. (2015). An analytical framework for supply network risk propagation: A Bayesian network approach. European Journal of Operational Research, 243(2), 618-627.

Gurtu, A., \& Johny, J. (2021). Supply Chain Risk Management: Literature Review. Risks, 9(1), 16.

Hahn, G. J., \& Kuhn, H. (2012). Value-based performance and risk management in supply chains: A robust optimization approach. International Journal of Production Economics, 139(1), 135-144.

Harland, C., Brenchley, R., \& Walker, H. (2003). Risk in supply networks. Journal of Purchasing and Supply Management, 9(2), 51-62.

Ho, W., Zheng, T., Yildiz, H., \& Talluri, S. (2015). Supply chain risk management: A 
literature review. International Journal of Production Research, 53(16), 5031-5069.

İSO 500. (2020). Türkiye'nin 500 Büyük Sanayi Kuruluşu 2020. Erişim adresi: https://www.iso500.org.tr/500-buyuk-sanayi-

kurulusu/2020/?ara=\&sektor_tipi=NACE\&sektor_kodu=29\&oda=\&calisan_sayisi= \&sermaye_yapisi= (Erişim tarihi: 17/11/2021).

Junaid, M., Xue, Y., \& Syed, M. W. (2020). Construction of index system for risk assessment in supply chains of automotive industry. International Journal of Supply Chain Management, 9(4), 91-106

Jüttner, U., Peck, H., \& Christopher, M. (2003). Supply chain risk management: outlining an agenda for future research. International Journal of Logistics Research and Applications, 6(4), 197-210.

Kull, T. J., \& Talluri, S. (2008). A Supply Risk Reduction Model Using Integrated Multicriteria Decision Making. IEEE Transactions on Engineering Management, 55(3), 409-419.

Kumar, S. K., Tiwari, M. K., \& Babiceanu, R. F. (2010). Minimisation of supply chain cost with embedded risk using computational intelligence approaches. International Journal of Production Research, 48(13), 3717-3739.

KPMG (2021). KPMG Perspektifinden Otomotiv Sektörüne Bakış. Erişim adresi: https://assets.kpmg/content/dam/kpmg/tr/pdf/2021/08/kpmg-perspektifindenotomotiv-sektorune-bakis-2021.pdf (Erişim tarihi: 21/11/2021).

Lawrence, J. M., Ibne Hossain, N. U., Jaradat, R., \& Hamilton, M. (2020). Leveraging a Bayesian network approach to model and analyze supplier vulnerability to severe weather risk: A case study of the U.S. pharmaceutical supply chain following Hurricane Maria. International Journal of Disaster Risk Reduction, 49, 101607.

Leedy, P. \& Ormrod, J. E. (2014). Practical research: Planning and design. Pearson Education.

Lin, Y., \& Zhou, L. (2011). The impacts of product design changes on supply chain risk: A case study. International Journal of Physical Distribution and Logistics Management, 41(2), 162-186.

Lune, H., \& Berg, B. L. (2017). Qualitative Research Methods for the Social Sciences (9. Bask1). Pearson.

Manuj, I., \& Mentzer, J. T. (2008). Global supply chain risk management. Journal of Business Logistics, 29(1), 133-155.

Meyer, A., Niemann, W., Uys, G., \& Beetge, D. (2019). An exploration of supply chain risk management in the South African third-party logistics industry. Acta Commercii, 19(1), 1-14.

Munir, M., Jajja, M. S. S., Chatha, K. A., \& Farooq, S. (2020). Supply chain risk management and operational performance: The enabling role of supply chain 
integration. International Journal of Production Economics, 227, 107667.

Mzougui, I., Carpitella, S., Certa, A., El Felsoufi, Z., \& Izquierdo, J. (2020). Assessing supply chain risks in the automotive industry through a modified MCDM-Based FMECA. Processes, 8(5), 579.

Nakandala, D., Lau, H., \& Zhao, L. (2017). Development of a hybrid fresh food supply chain risk assessment model. International Journal of Production Research, 55(14), 4180-4195.

Olson, D. L., \& Dash Wu, D. (2010). A review of enterprise risk management in supply chain. Kybernetes, 39(5), 694-706.

OSD. (2020). Otomotiv Sanayii Genel ve İstatistik Bülteni. Erişim adresi: http://www.osd.org.tr/sites/1/upload/files/YILLIK_2020-5479.pdf (Erişim tarihi: $18 / 11 / 2021)$.

Paul, S., Kabir, G., Ali, S. M., \& Zhang, G. (2020). Examining transportation disruption risk in supply chains: A case study from Bangladeshi pharmaceutical industry. Research in Transportation Business \& Management, 37, 100485.

Percy, W. H., Kostere, K., \& Kostere, S. (2015). Generic qualitative research in psychology. Qualitative Report, 20(2), 76-85.

Pettit, T. J., Croxton, K. L., \& Fiksel, J. (2013). Ensuring supply chain resilience: Development and implementation of an assessment tool. Journal of Business Logistics, 34(1), 46-76.

Prakash, S., Soni, G., \& Rathore, A. P. S. (2017). A critical analysis of supply chain risk management content: a structured literature review. Journal of Advances in Management Research, 14(1), 69-90.

Pişkin, S. (2017). Otomotiv sektör raporu: Türkiye otomotiv sanayii rekabet gücü ve talep dinamikleri perspektifinde 2020 iç pazar beklentileri. TSKB Ekonomik Araştırmalar. Erişim adresi: http://www.tskb.com.tr/i/content/3081_1_Otomotiv\%20Sektor\%20Raporu.pdf (Erişim tarihi: 15/04/2020).

Punniyamoorthy, M., Thamaraiselvan, N., \& Manikandan, L. (2013). Assessment of supply chain risk: Scale development and validation. Benchmarking, 20(1), 79-105.

Qazi, A., \& Akhtar, P. (2020). Risk matrix driven supply chain risk management: Adapting risk matrix based tools to modelling interdependent risks and risk appetite. Computers and Industrial Engineering, 139, 105351.

Rangel, D. A., De Oliveira, T. K., \& Leite, M. S. A. (2015). Supply chain risk classification: Discussion and proposal. International Journal of Production Research, 53(22), 6868-6887.

Ravindran, A. R., Ufuk Bilsel, R., Wadhwa, V., \& Yang, T. (2010). Risk adjusted multicriteria supplier selection models with applications. International Journal of 
Production Research, 48(2), 405-424.

Samvedi, A., Jain, V., \& Chan, F. T. S. (2013). Quantifying risks in a supply chain through integration of fuzzy AHP and fuzzy TOPSIS. International Journal of Production Research, 51(8), 2433-2442.

Sanayi ve Teknoloji Bakanlığı. (2020). Otomotiv Sektör Raporu. Erişim adresi: https://www.sanayi.gov.tr/assets/pdf/plan-program/OtomotivSektorRaporu2020.pdf (Erişim tarihi: 13/05/2020).

Sarkis, J. (2020). Supply chain sustainability: learning from the COVID-19 pandemic. International Journal of Operations \& Production Management, 41(1), 63-73.

Schlegel, G. L., \& Trent, R. J. (2014). Supply Chain Risk Management: An Emerging Discipline (1. Bask1). CRC Press.

Shahbaz, M. S., RM Rasi, R. Z., \& Bin Ahmad, M. F. (2019). A novel classification of supply chain risks: Scale development and validation. Journal of Industrial Engineering and Management, 12(1), 201-218.

Sodhi, M. S., \& Tang, C. S. (2012). Managing Supply Chain Risk. Springer.

Tang, C. S. (2006). Perspectives in supply chain risk management. International Journal of Production Economics, 103(2), 451-488.

Tang, C., \& Tomlin, B. (2008). The power of flexibility for mitigating supply chain risks. International Journal of Production Economics, 116(1), 12-27.

Tang, O., \& Musa, S. N. (2011). Identifying risk issues and research advancements in supply chain risk management. International Journal of Production Economics, 133(1), 25-34.

Thun, J. H., \& Hoenig, D. (2011). An empirical analysis of supply chain risk management in the German automotive industry. International Journal of Production Economics, 131(1), 242-249.

Trkman, P., \& McCormack, K. (2009). Supply chain risk in turbulent environments-A conceptual model for managing supply chain network risk. International Journal of Production Economics, 119(2), 247-258.

Tummala, R., \& Schoenherr, T. (2011). Assessing and managing risks using the Supply Chain Risk Management Process (SCRMP). Supply Chain Management, 16(6), 474483.

Tuncel, G., \& Alpan, G. (2010). Risk assessment and management for supply chain networks: A case study. Computers in Industry, 61(3), 250-259.

Üstündağ, A., ve Ungan, M. C. (2021). Covid-19 Sürecinde Tedarik Zinciri Risk Yönetimi. İçinde M. Akbolat ve Ö. Ünal (Ed.), COVID-19 Pandemisinde Işsletme Yönetiminin Dönüşümü (ss. 107-127). Gazi Kitabevi

Venkatesh, V. G., Rathi, S., \& Patwa, S. (2015). Analysis on supply chain risks in Indian 
apparel retail chains and proposal of risk prioritization model using Interpretive structural modeling. Journal of Retailing and Consumer Services, 26, 153-167.

Wagner, S. M., \& Bode, C. (2008). an Empirical Examination of Supply Chain Performance Along Several Dimensions of Risk. Journal of Business Logistics, 29(1), 307-325.

Wagner, S. M., \& Neshat, N. (2010). Assessing the vulnerability of supply chains using graph theory. International Journal of Production Economics, 126(1), 121-129.

Wu, T., Blackhurst, J., \& Chidambaram, V. (2006). A model for inbound supply risk analysis. Computers in Industry, 57(4), 350-365.

Wu, X., Zhang, C., \& Du, W. (2021). An Analysis on the Crisis of "chips shortage" in Automobile Industry-Based on the Double Influence of COVID-19 and Trade Friction. Journal of Physics: Conference Series, 1971(1), 012100.

Yıldırım, A., ve Şimsek, H. (2013). Sosyal Bilimlerde Nitel Araştırma Yöntemleri (9. Baskı). Seçkin.

Zhu, S. (2018). Supply Chain Risk Management in Automotive Industry (Yayınlanmamış Doktora Tezi). University of Windsor. 